\title{
CLIMATE WARMING: DOES NORTHWEST CHINA FACE A STARK FOOD SECURITY CHALLENGE?
}

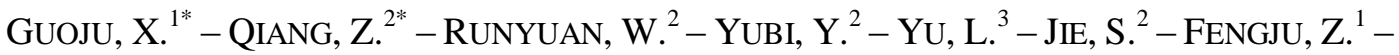 \\ JUYING, H. ${ }^{1}-$ FeI, M. ${ }^{1}-$ CHENGKE, L. ${ }^{1}-$ JING,W. $^{1}-$ HONG, Z. ${ }^{2}-$ Helin,W. ${ }^{2}-$ KAI, Z. ${ }^{2}$ \\ ${ }^{1}$ Institute of Environmental Engineering, Ningxia University, Yinchuan, Ningxia, 750021, China \\ ${ }^{2}$ Institute of Arid Meteorology, China Meteorological Administration, Gansu Key Laboratory of \\ Arid Climatic changes and Disaster Reduction, Lanzhou, Gansu Province 730020, China
}

${ }^{3}$ College of Chemical Engineering, Northwest University for Nationalities, Lanzhou 730000, China.

*Corresponding author

e-mail: xiaoguoju@hotmail.com; zhangqiang@cma.gov.cn

(Received $11^{\text {th }}$ Jul 2015; accepted $4^{\text {th }}$ Jun 2016)

\begin{abstract}
China's economy may be vulnerable to climate change, and Northwest China is an area sensitive to climate change. This review paper summarizes the impacts of climate warming on crop production in typical arid and semi-arid areas of Northwest China. Over the last 50 years, the climate has undergone a series of changes, including higher temperatures, increased drought and warmer winters. The future climate will become warmer and drought will become more severe. This will result in accelerated crop growth, more damage by crop pests, degraded soil, a decline in rain resource utilization, serious effects on the crop growing environment, weakening of agricultural ecological system stability, increased fluctuation in grain yield, difficulty in adjusting crop planting structure, threatened food nutrition and security, increased grain production costs, and risk and uncertainty in grain security. Taking scientific measures to actively keep pace with climate change will be a key strategy for reducing grain security risks in Northwest China.
\end{abstract}

Keywords: climate warming; crop; yield; quality; food security; semi-arid regions

\section{Introduction}

Climate change is predicted to increase both drought frequency and duration (Dai, 2011; Ponce-Campos et al., 2013). Arid and semi-arid regions account for $45 \%$ of the global land area, support 38\% of the global population and are among the regions with the most fragile ecological and water resource systems (Ye et al., 2015). In the past 100 years, the mean temperature increase of global arid regions was $0.94^{\circ} \mathrm{C}$, which is higher than the global mean temperature increase of $0.74^{\circ} \mathrm{C}$. Temperature increases in arid regions of each continent, except South America, were above the global mean temperature increase. In the past 100 years, abrupt changes in rainfall have been mostly in arid and semi-arid regions globally (Tollefson, 2015). Since the 1960s, rainfall in semi-arid regions of West Africa has decreased, with rainfall in the Sahel decreasing by $20-40 \%$. About 10-20\% of land in global arid and semi-arid regions have been seriously degraded, the area of extremely arid regions has doubled and the area of arid regions is close to $30 \%$. Large-scale droughts have recently occurred in North America, Africa, 
Europe, South America and Australia, resulting in major changes to terrestrial ecosystems, carbon balance and food security (Saleska et al., 2007;Piao et al., 2010).

The continuous aridification in the last 30 years in the semi-arid region of Northwest China has led to a serious environmental aggravation and lack of water resources, and has seriously restricted sustainable regional development. Northwest China, covering the Qinghai-Tibet Plateau and the Loess Plateau over Shaanxi, Gansu, Qinghai, Xinjiang, Ningxia and part of Inner Mongolia, consists of arid and semi-arid areas, semi-wet dry areas and dank and cold areas, and is sensitive to climate change (Fig. 1). Agriculture, comprising rain-fed and irrigated farming, dominates the national economy. However, grain production in this area has long been seriously restricted by drought (Chang et al., 2015). There is a narrow and long belt of frequent droughts in the semi-arid areas of north Shaanxi, mid-south Ningxia and mid-east Gansu, and there have been low, if any spring wheat yields over the past 10 years. It is questionable whether spring wheat is still suitable for growing in this area given the background of global warming.

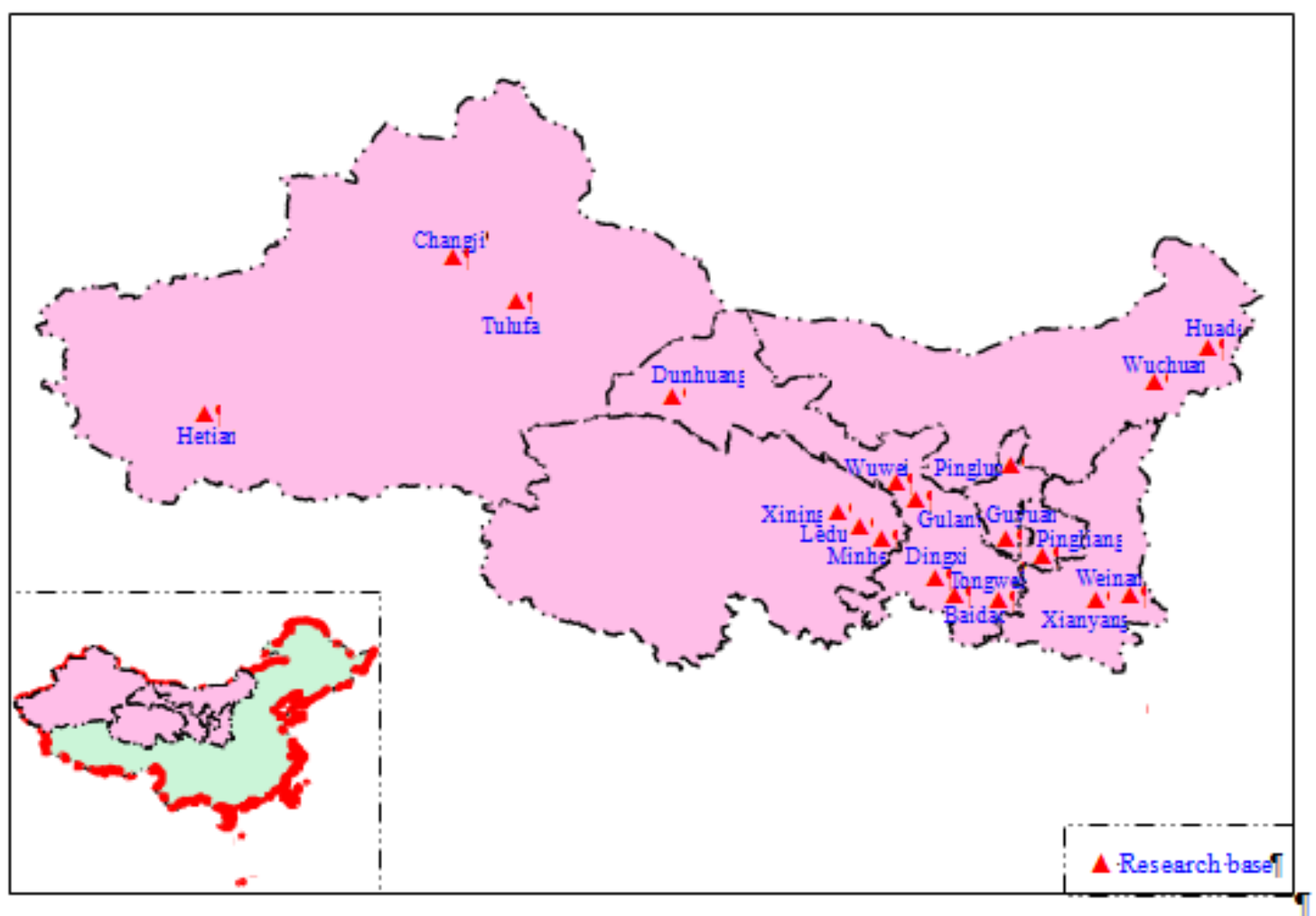

Figure 1. Map of northwest China. Over the past 10 years, researchers from Lanzhou Arid Meteorology Institute of the China Meteorological Administration and Ningxia University selected some experimental bases in Dingxi, Guyuan and Zhangye in typical arid and semi-arid areas of Northwest China to study the impacts of climate warming on crop production and provide important scientific information that can be used to improve grain security.

This paper aims to review climate observations and agricultural production trends in Northwest China and to use these observations to predict likely future changes. We 
highlight the main areas of vulnerability and sources of uncertainty based on recent literature and published data. The first section deals with the impact of recent climate change on food production, with particular attention to drought. Severe drought and rapid plant maturation are seriously threatening rain-fed crops in semi-arid regions. Increasing soil salinization and increases in plant diseases and insect pests are seriously threatening irrigated crops in arid regions. The second section deals with the main problems in agriculture caused by climate change, which has led to a decrease in agricultural ecological system stability, increased crop structure adjustment difficulties, threatened food nutrition, sharpened fluctuations in crop yield and an increase in the costs and investment needed for agricultural production. The last section integrates the measures taken against climate change, which mainly include selecting anti-drought species, adjusting crop structure, generalizing water saving techniques, developing cloud water resources, improving forecasting ability and developing low carbon agriculture.

\section{Grain production is influenced by multiple factors}

Over the past 50 years, the climate in Northwest China has experienced a series of changes, including higher temperatures, increased drought and warm winters. The future climate will continue to warm and droughts will become more severe.

\section{Drought}

The overall drought levels in Northwest China have become more severe. Extremely high and low temperature events have occurred and the frequency and duration of serious drought events have increased significantly (Lei et al., 2016). Over the past 50 years in Northwest China, spring drought has occurred in 43, summer drought in 37 and autumn drought in 28 of these years. Continuous spring and summer droughts have occurred in 22, continuous summer and autumn droughts in 17 and continuous spring, summer and autumn droughts in 14 of the past 50 years. In the 1990s, serious drought disasters occurred at a much higher frequency than previous years. In 1995, the drought disaster area in Gansu Province was 2,087,000 ha, the direct disaster area was 1,708,000 ha and $150.0 \times 10^{4} \mathrm{t}$ of grain yield was lost (Gao and Zhang, 2016). In 2000, the drought disaster area in Gansu Province was 1,622,000 ha, the direct disaster area was 566,000 ha and $114.2 \times 10^{4} \mathrm{t}$ of grain yield was lost (Lin et al., 2010). Based on the Fourth IPCC evaluation, by 2050 the temperature in Northwest China will rise by $1.93-2.77^{\circ} \mathrm{C}$; precipitation in mid-east Gansu, mid-south Ningxia and mid-north Shaanxi will decrease by $0.01-4.34 \%$; drought disasters will be much more frequent, the dry hot wind effect will worsen and drought restrictions on grain production will be much greater (Zhang et al., 2010; Deng et al., 2010).

\section{Rapid plant maturation}

It is well known that crop photosynthesis is influenced by excessively high temperatures. Some studies have shown that if temperature increases by $1.0-2.5^{\circ} \mathrm{C}$, then photosynthesis in spring wheat at the trefoil stage significantly declines, ear separation 
and formation is seriously affected and the number of ear grains significantly decreases. As temperature rises, the photosynthesis rate at booting stage will also significantly decrease, dry matter accumulation will be seriously affected, thousand-grain weight will significantly decline and yield of spring wheat will decline (Xiao et al., 2010). In the semi-arid rain-fed farming areas, the net photosynthesis rate and stomatal conductance of spring wheat at the milk filling and milk ripe stages declines as temperature rises, the transpiration rate increases and dry matter accumulation decreases (Zhao et al., 2007a). The warming climate accelerates crop growth, shortens the growth duration and seriously decreases crop yield. Studies have shown that if temperature rises $0.6-2.2^{\circ} \mathrm{C}$, the full growth period of peas in semi-arid rain-fed farming areas will be shortened by $3-17 \mathrm{~d}$ (Xiao et al., 2009) and the full growth period of corn in the semi-arid irrigated area will be shortened by $4-17 \mathrm{~d}$ (Wang et al., 2004). If temperature rises $0.5-2.0^{\circ} \mathrm{C}$, the full growth duration of the pea-spring wheat-potato rotation system in semi-arid rain-fed areas will be shortened by 11-42 d (Table 1).

\section{Crop pests and diseases}

Because of the warming climate, pest breeding periods will be prolonged, the growth of bacteria and pests will accelerate, pest lifecycles will be shortened and there will be more pest generations. Warm winters in Northwest China favor pest breeding and enable them to live through winter, thus the crop pest problem will increase as winters get warmer. Warm springs favor pest breeding because the dry and rainless weather in spring creates favorable conditions for wheat aphids and wheat spider mite (Deng et al., 2012). The occurrence of wheat sharp eyespot, powdery mildew and wheat spider mite are correlated with climate change (Zhao et al., 2005). The incidence of stripe rust (Liu et al., 2009), corn bollworm and red spider mite (Zheng et al., 2001), pea root rot (Xiao et al., 2009) and potato late blight in Northwest China has increased as temperature has risen, and the area affected by diseases and pests has risen by 3.5\% annually (Yao et al., 2010).

\section{Accelerated soil degradation}

The rate at which loess becomes soil in the semi-arid areas is correlated with temperature and rainfall. Climate warming accelerates decomposition of soil organic matter, which leads to a decline in soil fertility; and ion exchange in soil increases and soil pollution becomes worse ( $\mathrm{Li}$ et al., 2009). Climate warming also accelerates the upward movement of salts as the soil water content drops, which leads to an increase in salinity of the farming layer (Fig. 2). If the temperature rises by $0.5-2.5^{\circ} \mathrm{C}$ in winter, the effective nitrogen in soil will decrease by $2.45-4.66 \mathrm{~g} / \mathrm{kg}$ (Xiao et al., 2012) and soil salinity will increase by $0.39-0.50 \mathrm{~g} / \mathrm{kg}$. It is estimated that the irrigation water needed to neutralize the increase in salinity caused by climate warming will be $129,000,000-140,000,000 \mathrm{~m}^{3}$ in the Ningxia Yellow River Irrigation Area. After winter warming, the water content in soil in arid areas will significantly decrease. If the temperature rises by $0.5-2.5^{\circ} \mathrm{C}$ in winter, then the water content in the crop growing layer of the soil will decrease from $18.5 \%$ to $16.2-12.5 \%$ (Xiao et al., 2010). 
Table 1. Influence of climate change on crop growth in Northwest China

\begin{tabular}{|c|c|c|c|c|c|}
\hline & $\begin{array}{l}\text { Meteorological data/simulation } \\
\text { experiment }\end{array}$ & Trend in climate change & Crop growth & Yield and quality change & Reference \\
\hline \multirow{5}{*}{$\begin{array}{l}\text { Spring } \\
\text { wheat }\end{array}$} & $\begin{array}{l}\text { Data from positioned observations, } \\
\text { encrypted observations and } \\
\text { corresponding parallel } \\
\text { meteorological observations for } \\
\text { spring wheat growing during } \\
\text { 1986-2009. Experimental base: } \\
\text { Dingxi. }\end{array}$ & $\begin{array}{l}\text { Annual temperature } \\
\text { significantly increased, the } \\
\text { temperature change rate was } \\
0.362^{\circ} \mathrm{C} / 10 \text { years; the annual } \\
\text { rainfall decreased and the } \\
\text { rate of rainfall change was } \\
-15.796 \mathrm{~mm} / 10 \text { years. }\end{array}$ & $\begin{array}{l}\text { Growth of spring wheat was influenced by } \\
\text { climate warming. The period of milky } \\
\text { ripeness-maturity was shortened by } 2-3 \\
\text { d/10 years, and the full growing period was } \\
\text { shortened by } 4-5 \text { d/ } 10 \text { years. Climate } \\
\text { warming accelerated the growth of spring } \\
\text { wheat and shortened the full growing period. }\end{array}$ & $\begin{array}{l}\text { Annual yield of spring wheat decreased by } \\
-34.584 \mathrm{~g} / \mathrm{m}^{2} / 10 \text { years. Due to climate } \\
\text { warming, the influence of meteorological } \\
\text { conditions on the growth and yield of spring } \\
\text { wheat increased and was affected by more } \\
\text { indeterminate factors. }\end{array}$ & $\begin{array}{l}\text { Yao et al. } \\
(2011 \mathrm{c})\end{array}$ \\
\hline & $\begin{array}{l}\text { Meteorological data and positioned } \\
\text { observation data for the growth of } \\
\text { spring wheat during 1986-2004. } \\
\text { Experimental base: Dingxi, } \\
\text { Tongwei. }\end{array}$ & 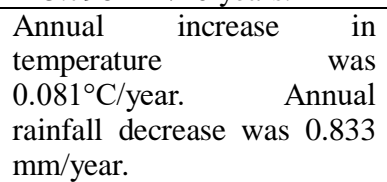 & $\begin{array}{l}\text { Growth period of spring wheat was } \\
\text { advanced and shortened. Growth period was } \\
\text { shortened by about } 1.7 \mathrm{~d} \text { while temperature } \\
\text { rose by } 1^{\circ} \mathrm{C} \text {. }\end{array}$ & Spring wheat yields decreased. & $\begin{array}{l}\text { Zhao et al. } \\
\text { (2007a) }\end{array}$ \\
\hline & $\begin{array}{l}\text { Meteorological data and positioned } \\
\text { observation data for the growth of } \\
\text { spring wheat during 1986-2005. } \\
\text { Experimental base: Dingxi. }\end{array}$ & $\begin{array}{l}\text { Daily mean annual } \\
\text { temperature increased by } \\
0.0786^{\circ} \mathrm{C} / \text { year; annual } \\
\text { rainfall decreased by } 1.876 \\
\text { mm/year. }\end{array}$ & $\begin{array}{l}\text { Growth period of spring wheat advanced by } \\
0.195 \mathrm{~d} / \text { year. }\end{array}$ & $\begin{array}{l}\text { Annual yield of spring wheat declined by } 5.5 \\
\mathrm{~g} / \mathrm{m}^{2} \text {; the yield fell by } 1.2 \mathrm{~g} / \mathrm{m}^{2} \text { and the annual } \\
\text { rainfall declined by } 1 \mathrm{~mm} \text {. The main } \\
\text { meteorological factor influencing the growing } \\
\text { days and yield of spring wheat in the semi-arid } \\
\text { rain-fed farming area was the change in rainfall. }\end{array}$ & $\begin{array}{l}\text { Zhao et al. } \\
\text { (2007b) }\end{array}$ \\
\hline & $\begin{array}{l}\text { Meteorological data and positioned } \\
\text { observation data for the growth of } \\
\text { spring wheat during 1955-2005. } \\
\text { Experimental base: Huade, } \\
\text { Wuchuan. }\end{array}$ & $\begin{array}{l}\text { Annual mean temperature } \\
\text { increased by } 0.40^{\circ} \mathrm{C} / \text { year, } \\
\text { but the change in annual } \\
\text { rainfall was not significant. }\end{array}$ & $\begin{array}{l}\text { Growth period of spring wheat was } \\
\text { significantly shortened by } 24 \mathrm{~d} \text {, the seeding } \\
\text { period was significantly delayed by } 17 \mathrm{~d} \text {, the } \\
\text { emergence period was postponed, the } \\
\text { maturing period was advanced and the } \\
\text { whole growing period was shortened. }\end{array}$ & $\begin{array}{l}\text { Yield of spring wheat decreased significantly. } \\
\text { Planted area of spring wheat declined year on } \\
\text { year in the warm-cool semi-arid area. }\end{array}$ & $\begin{array}{l}\text { Hou, et al. } \\
\text { (2009) }\end{array}$ \\
\hline & $\begin{array}{l}\text { Meteorological data and positioned } \\
\text { observation data for the growth of } \\
\text { irrigated spring wheat during } \\
\text { 1981-2005. Experimental base: } \\
\text { Wuwei. }\end{array}$ & $\begin{array}{l}\text { Annual increase in daily } \\
\text { mean temperature was } \\
0.0374^{\circ} \mathrm{C} / \text { year and rainfall } \\
\text { increased by } 0.19 \mathrm{~mm} \text {. }\end{array}$ & $\begin{array}{l}\text { Seeding, elongation, blooming and maturing } \\
\text { periods of spring wheat were advanced by } \\
-0.345,-0.962,-1.997 \text { and }-0.136 \mathrm{~d} / \text { year, } \\
\text { respectively. }\end{array}$ & $\begin{array}{l}\text { Yield of spring wheat increased by } 8.8 \\
\mathrm{~g} / \mathrm{m}^{2} / \text { year. Accumulated temperature rose by } \\
1^{\circ} \mathrm{C} \text {. The main meteorological factor } \\
\text { influencing the full growing days and yield of } \\
\text { irrigated spring wheat in the arid area was the } \\
\geq{ }^{\circ} \mathrm{C} \text { accumulated temperature and sunshine } \\
\text { hours. The influence of rainfall was not } \\
\text { significant. }\end{array}$ & $\begin{array}{l}\text { Cao et al. } \\
(2008)\end{array}$ \\
\hline
\end{tabular}




\begin{tabular}{|c|c|c|c|c|c|}
\hline & $\begin{array}{l}\text { Meteorological data and positioned } \\
\text { observation data for the growth of } \\
\text { irrigated spring wheat during } \\
\text { 1981-2005. Experimental base: } \\
\text { Dunhuang. }\end{array}$ & $\begin{array}{l}\text { Annual increase in daily } \\
\text { mean temperature was } \\
0.0687^{\circ} \mathrm{C} / \text { year. The annual } \\
\text { rainfall change was }-0.319 \\
\text { mm/year. }\end{array}$ & $\begin{array}{l}\text { Seeding period of spring wheat was delayed } \\
\text { by } 0.02 \mathrm{~d} / \text { year. The elongation, blooming, } \\
\text { maturing and full growing periods were } \\
\text { advanced by }-0.188,-0.413,-0.341 \text { and } \\
-0.370 \mathrm{~d} / \text { year, respectively. }\end{array}$ & $\begin{array}{l}\text { Yield of spring wheat decreased by } 0.3 \\
\mathrm{~g} / \mathrm{m}^{2} / \text { year. The main meteorological factors } \\
\text { influencing the full growing days of irrigated } \\
\text { spring wheat in the arid area were daily mean } \\
\text { temperature, rainfall and sunshine hours. }\end{array}$ & $\begin{array}{l}\text { Cao et al. } \\
(2008)\end{array}$ \\
\hline & $\begin{array}{l}\text { Meteorological data and positioned } \\
\text { observation data for the growth of } \\
\text { spring wheat during } 1980-2007 . \\
\text { Experimental base: Minhe. }\end{array}$ & $\begin{array}{l}\text { Annual mean temperature } \\
\text { and the highest and lowest } \\
\text { temperatures significantly } \\
\text { increased. }\end{array}$ & $\begin{array}{l}\text { Sowing period was delayed, maturing period } \\
\text { was advanced and growing period was } \\
\text { shortened by } 11.7 \mathrm{~d} \text { if the daily mean } \\
\text { temperature increased by } 1^{\circ} \mathrm{C} \text { during the } \\
\text { growing period. }\end{array}$ & $\begin{array}{l}\text { There was a large fluctuation in yields. Climate } \\
\text { warming accelerated the growing of spring } \\
\text { wheat in the irrigated farming areas in the } \\
\text { Qinghai plateau, but decreased the yield. }\end{array}$ & $\begin{array}{l}\text { Wang et al. } \\
\text { (2011b) }\end{array}$ \\
\hline & $\begin{array}{l}\text { Infrared radiator farm warming } \\
\text { simulation } \\
\text { Experimental base: Pingluo. }\end{array}$ & $\begin{array}{l}\text { Temperature increased by } \\
2.0-2.5^{\circ} \mathrm{C} \text {. }\end{array}$ & $\begin{array}{l}\text { Full growing period of spring wheat was } \\
\text { shortened by } 18-22 \mathrm{~d} \text {. }\end{array}$ & $\begin{array}{l}\text { Yield of spring wheat was reduced by } \\
16.5-18.5 \% \text {. Photosynthesis rate of irrigated } \\
\text { spring wheat in the arid area during the trefoil } \\
\text { and booting stages was decreased by warming, } \\
\text { and so the yield was reduced by the decrease in } \\
\text { the number of grains and the thousand-grain } \\
\text { weight. }\end{array}$ & $\begin{array}{l}\text { Xiao et al. } \\
\text { (2011a) }\end{array}$ \\
\hline & $\begin{array}{l}\text { Simulated sunshine greenhouse } \\
\text { warming experiment. Experimental } \\
\text { base: Dingxi. }\end{array}$ & $\begin{array}{l}\text { Temperature increased by } \\
0.6-2.2^{\circ} \mathrm{C} \text {. }\end{array}$ & $\begin{array}{l}\text { Full growing period was shortened by } \\
\text { warming. }\end{array}$ & $\begin{array}{l}\text { Contents of } \mathrm{Cd} \text { and } \mathrm{Zn} \text { in the grain of spring } \\
\text { wheat exceeded the standard values by } 490 \text { and } \\
27 \% \text {, respectively. The quality of spring wheat } \\
\text { was influenced by climate warming. }\end{array}$ & $\begin{array}{lrl}\mathrm{Li} & \text { et } & \text { al. } \\
(2012)\end{array}$ \\
\hline & $\begin{array}{l}\text { Data from positioned observations, } \\
\text { encrypted observations and } \\
\text { corresponding parallel } \\
\text { meteorological observations for } \\
\text { winter wheat during 1980-2010. } \\
\text { Experimental base: Dingxi. }\end{array}$ & $\begin{array}{l}\text { There was a rising trend in } \\
\text { annual temperature change. } \\
\text { The rate of temperature } \\
\text { change was } 0.325^{\circ} \mathrm{C} / 10 \\
\text { years. }\end{array}$ & $\begin{array}{l}\text { Seeding period of winter spring was delayed } \\
\text { by } 2-3 \mathrm{~d} / 10 \text { years, Greening period was } \\
\text { advanced by } 4-5 \mathrm{~d} / 10 \text { years and Blooming } \\
\text { and maturing periods were advanced by } 5-6 \\
\mathrm{~d} / 10 \text { years. Wintering period of winter } \\
\text { spring was shortened by } 5-6 \mathrm{~d} / 10 \text { years and } \\
\text { Full growing period was shortened by } 7-8 \\
\text { d/10 years. }\end{array}$ & $\begin{array}{l}\text { Temperature change during the } \\
\text { seeding-wintering-elongating-blooming } \\
\text { periods of winter wheat in the semi-arid area of } \\
\text { the Loess Plateau influenced yield. The rainfall } \\
\text { change during the seeding-elongation period } \\
\text { influenced yield. }\end{array}$ & $\begin{array}{l}\text { Yao et al. } \\
\text { (2011) }\end{array}$ \\
\hline & $\begin{array}{l}\text { Meteorological data and position } \\
\text { observation data for the growth of } \\
\text { winter wheat during 1981-2004. } \\
\text { Experimental base: Guyuan. }\end{array}$ & $\begin{array}{l}\text { Annual mean temperature } \\
\text { increased, but the annual } \\
\text { rainfall decreased. }\end{array}$ & $\begin{array}{l}\text { Shortening of the wintering-greening period } \\
\text { was significantly correlated with the } \\
\text { extremely low temperature. Shortening of } \\
\text { the milky ripeness-maturing period was } \\
\text { significantly correlated with extremely high } \\
\text { temperature, and prolonging of the } \\
\text { greening-elongating and blooming-milky } \\
\text { ripeness periods was significantly correlated } \\
\text { with extremely low temperature. }\end{array}$ & $\begin{array}{l}\text { Yield of winter wheat in the semi-arid area of } \\
\text { the Loess Plateau was significantly and } \\
\text { positively correlated with the lowest } \\
\text { temperature in the wintering period; however, } \\
\text { the highest temperature in the greening-booting } \\
\text { and milky ripeness-maturing periods was } \\
\text { significantly and negatively correlated with } \\
\text { yield. }\end{array}$ & $\begin{array}{l}\text { Zhang et } \\
\text { al. (2008) }\end{array}$ \\
\hline
\end{tabular}




\begin{tabular}{|c|c|c|c|c|c|}
\hline & $\begin{array}{l}\text { Meteorological data and positioned } \\
\text { observation data for the growth of } \\
\text { spring wheat during 1981-2005. } \\
\text { Experimental base: Tongwei. }\end{array}$ & $\begin{array}{l}\text { Annual temperature } \\
\text { significantly increased and } \\
\text { annual rainfall decreased. }\end{array}$ & $\begin{array}{l}\text { Growing period of winter wheat was } \\
\text { shortened by } 0.6-1.3 \mathrm{~d} / \text { year. }\end{array}$ & $\begin{array}{l}\text { Temperature rise and rainfall decrease increased } \\
\text { the annual yield of winter wheat by } 43.2-91.6 \\
\mathrm{~kg} / \mathrm{ha} \text {. It was estimated that the yield will } \\
\text { increase } 3.1-4.0 \% \text { by } 2030 \text { in the semi-wet dry } \\
\text { area. }\end{array}$ & $\begin{array}{l}\text { Xiao et al. } \\
(2008)\end{array}$ \\
\hline & $\begin{array}{l}\text { Meteorological data and positioned } \\
\text { observation data for the growth of } \\
\text { spring wheat during } 1960-2010 . \\
\text { Experimental base: Xianxiang and } \\
\text { Weinan. }\end{array}$ & $\begin{array}{l}\text { Annual mean temperature } \\
\text { increased significantly, with } \\
\text { a large increase in } \\
\text { temperature in spring and } \\
\text { winter. However, annual } \\
\text { rainfall decreased, } \\
\text { significantly in spring and } \\
\text { autumn. }\end{array}$ & $\begin{array}{l}\text { Greening period of winter wheat advanced } \\
\text { by } 9 \mathrm{~d} \text { and the elongating period advanced } \\
\text { by } 7 \mathrm{~d} \text { during 2000-2007 compared to } \\
1989-1999 .\end{array}$ & $\begin{array}{l}\text { Because of the excessively high temperature, } \\
\text { the wintering period of winter wheat was } \\
\text { shortened, the soil moisture fell faster and the } \\
\text { wheat seedlings grew more rapidly. In the dry } \\
\text { plateau of Weibei, the growing of winter wheat } \\
\text { was significantly influenced by climate } \\
\text { warming. }\end{array}$ & $\begin{array}{l}\text { Yang et al. } \\
(2010) \text {; } \\
\text { Gao et al. } \\
(2012)\end{array}$ \\
\hline & $\begin{array}{l}\text { Meteorological data and positioned } \\
\text { observation data for the growth of } \\
\text { spring wheat during 1981-2004. } \\
\text { Experimental base: Hetian, } \\
\text { Changji. }\end{array}$ & $\begin{array}{l}\text { Both temperature and } \\
\text { rainfall increased. }\end{array}$ & $\begin{array}{l}\text { Sowing period for winter wheat was delayed } \\
\text { by } 2-6 \mathrm{~d} / 10 \text { years, the greening period was } \\
\text { delayed by } 4.7 \mathrm{~d} / 10 \text { years, the maturing } \\
\text { period was advanced by } 7.7 \mathrm{~d} / 10 \text { years and } \\
\text { the number of days in the greening-maturing } \\
\text { period was shortened by about } 16-19 \mathrm{~d} \text {. }\end{array}$ & $\begin{array}{l}\text { Yield of winter wheat was significantly } \\
\text { influenced by rising temperature. The growth of } \\
\text { winter wheat after greening was accelerated, the } \\
\text { growing period was shortened, the maturing } \\
\text { period was generally advanced and the climate } \\
\text { conditions were not favorable for the } \\
\text { production of local winter wheat. }\end{array}$ & $\begin{array}{l}\text { Du et al. } \\
(2011)\end{array}$ \\
\hline & $\begin{array}{l}\text { Infrared radiator farm warming } \\
\text { simulation } \\
\text { Experimental base: Tongwei. }\end{array}$ & $\begin{array}{l}\text { Temperature increased by } \\
0.6-2.5^{\circ} \mathrm{C} \text {. }\end{array}$ & $\begin{array}{l}\text { An increase in the mean daily temperature of } \\
1.4-2.2^{\circ} \mathrm{C} \text { led to a decrease in duration of } \\
\text { the growth stages by } 11-21 \mathrm{~d} \text {. }\end{array}$ & $\begin{array}{l}\text { An increase in temperature will improve the } \\
\text { winter wheat yield. It was predicted that } \\
\text { climatic changes may lead to the increase of } \\
2.6-6.0 \% \text { in annual wheat yields. }\end{array}$ & $\begin{array}{l}\text { Xiao et al. } \\
(2010)\end{array}$ \\
\hline Pea & $\begin{array}{l}\text { Infrared radiator farm warming } \\
\text { simulation experiment. } \\
\text { Experimental base: Tongwei. }\end{array}$ & $\begin{array}{l}\text { Temperature increased by } \\
0.6-2.5^{\circ} \mathrm{C} \text {. }\end{array}$ & $\begin{array}{l}\text { Growing period for pea was shortened by } \\
3-17 \mathrm{~d} \text {. }\end{array}$ & $\begin{array}{l}\text { Pea yields were reduced by } 6.3-17.5 \% \text {. Over } \\
\text { the last } 20 \text { years, pea has disappeared from the } \\
\text { semi-arid rain-fed farming area of } \\
34^{\circ} 55^{\prime}-35^{\circ} 26^{\prime} \mathrm{N} \text {. }\end{array}$ & $\begin{array}{l}\text { Xiao et al. } \\
(2009)\end{array}$ \\
\hline $\begin{array}{l}\text { Crop } \\
\text { rotation }\end{array}$ & $\begin{array}{l}\text { Infrared radiator farm warming } \\
\text { simulation } \\
\text { Experimental base: Guyuan. }\end{array}$ & $\begin{array}{l}\text { Temperature increased by } \\
0.5-2.0^{\circ} \mathrm{C} \text {. }\end{array}$ & $\begin{array}{l}\text { Growing period of the crop rotation system } \\
\text { of pea-spring wheat-potato was shortened } \\
\text { by } 11-42 \mathrm{~d} \text {. }\end{array}$ & $\begin{array}{l}\text { Yield of the crop rotation system: pea-spring } \\
\text { wheat-potato, was reduced by } 3.2-9.4 \% \text {. In the } \\
\text { semi-arid area of the Loess Plateau, the crop } \\
\text { rotation system was significantly influenced by } \\
\text { climate warming over the long term. }\end{array}$ & $\begin{array}{l}\text { Xiao et al. } \\
(2007 b)\end{array}$ \\
\hline
\end{tabular}




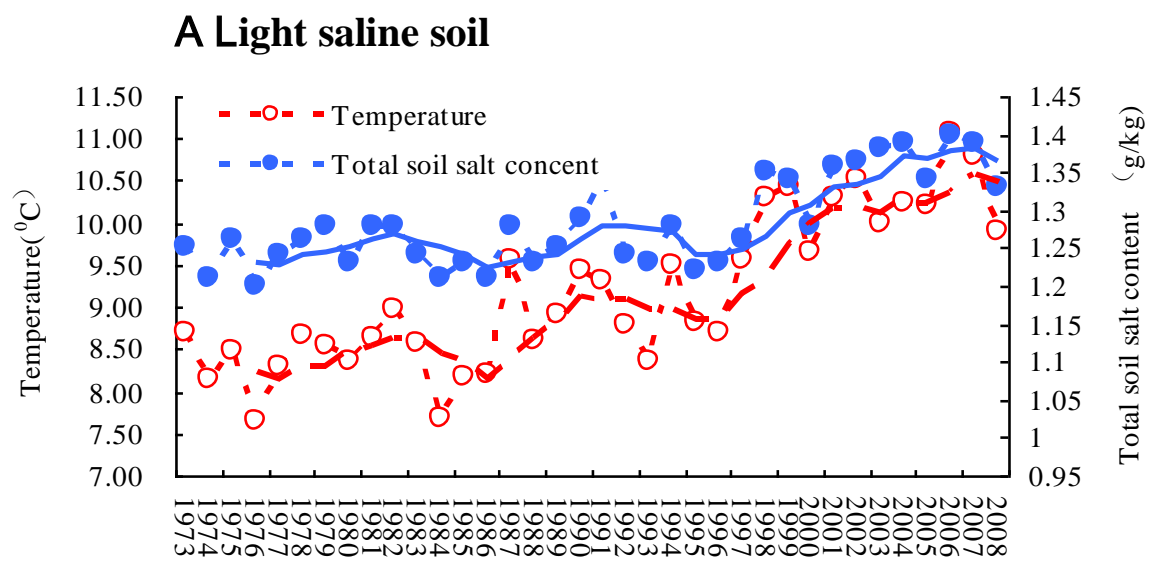

\section{B Moderate saline soil}

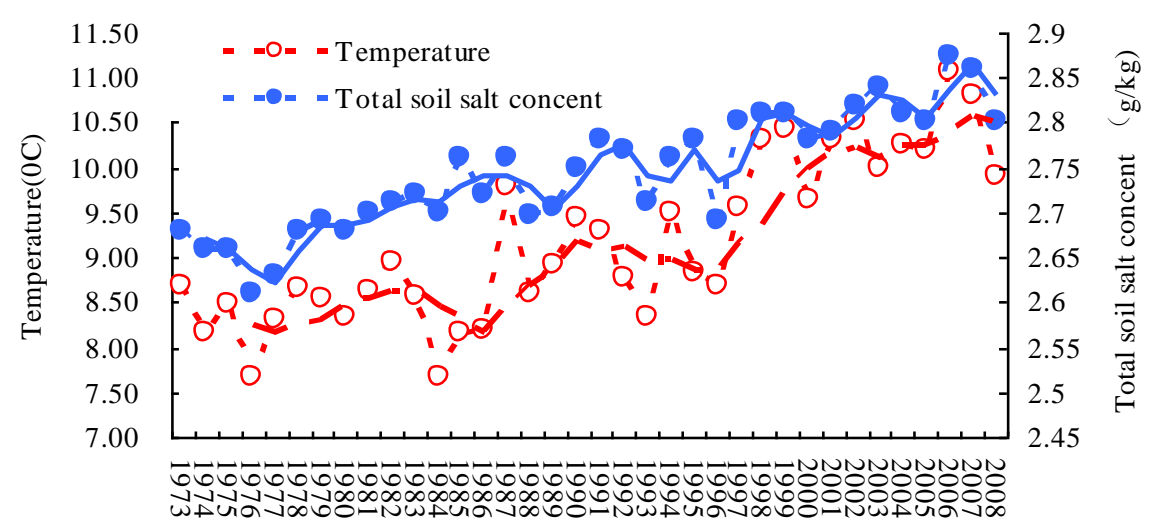

\section{Severe saline soil}

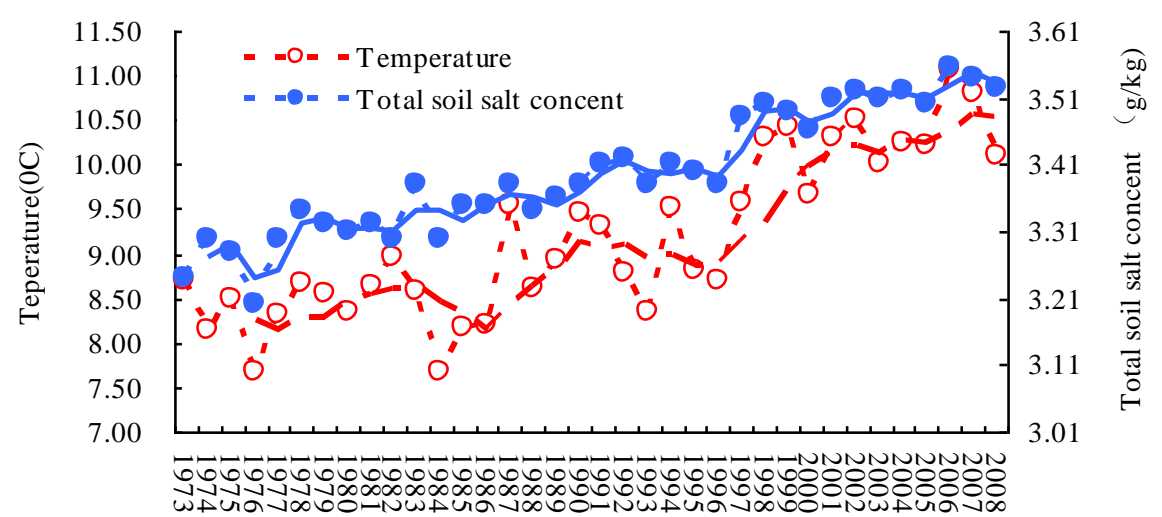

Figure 2. The change trends for annual average temperature and total salt content in saline soil during 1973-2008.

Climatic warming has intensified soil moisture evaporation and has led to soil salinity moving upward, resulting in increases in the harm caused by salt and alkali in soil. This figure shows observational, soil salinity and meteorological data over the past 35 years and the influence of climatic warming on soil salinity change in the Yellow River Irrigation Area in Ningxia Hui Autonomous Region. The total soil salt content has an increasing trend because of global climatic warming over the past 35 years, and the total salt content of light, moderate and severe saline soils has increased by $0.08,0.13$ and $0.19 \mathrm{~g} / \mathrm{kg}$, respectively (Xiao et al, 2010). 


\section{Decreased rain resource utilization ratio}

Climate warming directly influences crop photosynthesis and transpiration, accelerates soil moisture evaporation and influences the effective utilization of water. Over the past 50 years, the temperature in semi-arid rain-fed farming areas has risen by $0.6-1.6^{\circ} \mathrm{C}$, rainfall has decreased from 105.6 to $67.7 \mathrm{~mm}$ and the water utilization rate of spring wheat has decreased by $0.3-0.5 \mathrm{~kg} / \mathrm{hm}^{2}$. In the future, if temperature rises by $0.5-2.5^{\circ} \mathrm{C}$, the pea water utilization rate will decrease by $4.3-33.3 \%$, and the water utilization rate of the spring wheat-pea-potato rotation system will decrease by $3.0-12.4 \%$. If the temperature rise is $<1.5^{\circ} \mathrm{C}$ and annual rainfall is $>310.0 \mathrm{~mm}$, then the water utilization rate of potato will still increase. However, if the temperature rise is $>$ $1.5^{\circ} \mathrm{C}$ and the rainfall is $<310.0 \mathrm{~mm}$, then the water utilization rate of potato will decrease. The global climate change over the next 50 years will negatively influence the general water utilization of crops in Northwest China (Table 2).

\section{Decreased utilization of trace elements}

Climate warming will decrease biological utilization and increase the concentration of trace elements by influencing soil microorganism and cell enzyme activities. Studies have shown that if the temperature rises by $1^{\circ} \mathrm{C}$, the concentrations of cadmium $(\mathrm{Cd})$, lead $(\mathrm{Pb})$, copper $(\mathrm{Cu})$, zinc $(\mathrm{Zn})$ and manganese $(\mathrm{Mn})$ will increase by 5.8, 2.8, 4.4, 90.6 and $3.6 \%$, respectively ( $\mathrm{Li}$ et al., 2011). If warming continues, it is estimated that by 2050, the contents of $\mathrm{Cd}$ and $\mathrm{Zn}$ in spring wheat kernels in the semi-arid rain-fed farming area of Northwest China will exceed acceptable values by 490 and 27\%, respectively, and iron $(\mathrm{Fe})$ and $\mathrm{Zn}$ will transfer from soil to potato stem tubers and leaves at an increased rate (Fig. 3). Climate change will decrease the utilization rate of trace elements, reduce protein and reducing sugar contents and significantly degrade crop quality.

\section{Food security will be challenged by many problems}

Climate warming negatively affects the agricultural ecosystem in Northwest China, increases grain yield fluctuations, modifies crop structure, threatens grain nutritional security, increases grain production investment and increases grain security risk and uncertainty.

\section{Decreased agricultural ecosystem stability}

Different species have different responses to global climate change and the composition of agricultural ecosystems will significantly change with global climate change. Warming raises the respiratory activity of agricultural ecosystems, accelerates the mineralization of soil organic carbon and reduces carbon storage in the ecosystem. Climate warming accelerates the decomposition of organic matter in the soil, promotes soil ion change and increases soil pollution. It accelerates soil water evaporation and increases saline and alkali damage to the soil farming layer. Climate warming can modify the solubility of trace elements in the soil by influencing soil microorganism activity, 
crop growth rates, photosynthesis rates and cell enzymatic activity (Li et al., 2013). This means that climate change will modify agricultural ecosystem composition, structure, function and biodiversity and reduce ecosystem stability.

\section{Increased crop structural adjustment}

Climate warming considerably improves the effective heat reserve, prolongs the frost-free period and substantially modifies crop structure (Leng et al., 2015). Over the past 50 years, the growth period starting date of suitable crops in Northwest China has advanced, the termination date postponed and the crop growth period prolonged. Compared with 1951-1980, the northern planting border for winter wheat in Shaanxi, Inner Mongolia and Qinghai during 1981-2007 moved northwards and westwards. In the 1970s, the northern planting border for winter wheat in Ningxia was $36^{\circ} \mathrm{N}$, but now it has extended to $39^{\circ} \mathrm{N}$ in the Yellow River Irrigation Area. However, the most-suitable areas and suitable areas for potato growing have been reduced by 35 and 3\%, respectively; the less suitable areas and plantable areas have increased by 18.5 and $6.6 \%$, respectively, and the unsuitable area has been reduced by $2.0 \%$. The potato and corn planting areas have extended from south to north and from low to high altitude and have gradually got larger over the years (Yao et al., 2010a). Over the past 30 years, the altitude of suitable planting areas for spring wheat, pea and potato in the Qilianshan mountainous area have risen by 100-200 m, suitable planting areas for potato in mid-east Gansu have risen by 100-200 m and suitable planting areas for corn in the Gansu Corridor have risen by about $150 \mathrm{~m}$ (Table 3).

\section{Contribution to the shortage of water resources}

Climate change has led to the spatial and temporal variations of temperature and precipitation, which may result in hydrological drought and water shortage on the Hexi Corridor in the semi-arid climate zone of Northwest China (Gao and Zhang, 2016). The Weihe River, the largest tributary of the Yellow River, experienced runoff declines as large as $35 \%$ in the last century. The results showed that precipitation and runoff have decreased since the baseline decade. We further estimated the relative contributions of human activity and climate change to the hydrological response of the Weihe River Basin and determined that human activity has a greater impact on basin runoff than climate change factors. The percentages in change of runoff due to climate change were 36,28 , 53 and 10\% in the 1970s, 1980s 1990s and 2000s, respectively (Chang et al., 2015). The seasonal changes in temperature and rainfall may have positive impacts on water quality. However, an extremely cold spring and high wind speed are likely to affect the self-stabilizing equilibrium states of the reservoir, which requires attention in the future. This study provides useful information regarding the potential effects of climate change on water quality in China (Zhang et al., 2015a). 
Table 2. Influence of climate change on soil and crop moisture utilization

\begin{tabular}{|c|c|c|c|c|}
\hline Area & $\begin{array}{l}\text { Meteorological data analysis/ } \\
\text { simulation experiment }\end{array}$ & Climate change & Crop moisture utilization/soil moisture change & Reference \\
\hline \multirow{8}{*}{$\begin{array}{l}\text { Semi-arid rain-fed } \\
\text { farming area }\end{array}$} & $\begin{array}{l}\text { Soil moisture data and corn } \\
\text { yield data during 1990-2007. }\end{array}$ & $\begin{array}{l}\text { Temperature increased, rainfall } \\
\text { decreased, soil evaporation increased } \\
\text { and drought occurred more frequently. }\end{array}$ & $\begin{array}{l}\text { Soil moisture storage was most significantly correlated with } \\
\text { corn yield in the elongating-heading period. In the } \\
\text { elongating-heading period from } 0-50 \mathrm{~cm} \text {, the yield increased } \\
\text { by } 180-210 \mathrm{~kg} / \mathrm{hm}^{2} \text { if the soil moisture storage increased by } 10 \\
\mathrm{~mm} .\end{array}$ & $\begin{array}{l}\text { Wang et al. } \\
(2009)\end{array}$ \\
\hline & $\begin{array}{l}\text { Rainfall, soil temperature and } \\
\text { soil moisture data during } \\
\text { 1970-2005. }\end{array}$ & $\begin{array}{l}\text { Soil temperature at } 0-10 \text { and } 10-20 \mathrm{~cm} \\
\text { depth increased by } 0.9 \text { and } 0.5^{\circ} \mathrm{C} \text {, } \\
\text { respectively. }\end{array}$ & $\begin{array}{l}\text { Soil moisture storage was low during May-June and } \\
\text { July-August. Soil moisture storage was insufficient during } \\
\text { May-August and corn growth was affected during } \\
\text { September-October. Moisture and temperature were suitable for } \\
\text { soil moisture storage, but not suitable for corn maturing during } \\
\text { the later period. }\end{array}$ & $\begin{array}{l}\text { Yao et al. } \\
(2010 \mathrm{~b})\end{array}$ \\
\hline & $\begin{array}{l}\text { Annual mean temperature, } \\
\text { highest temperature, lowest } \\
\text { temperature, relative humidity } \\
\text { and rainfall data during } \\
\text { 1961-2008. }\end{array}$ & $\begin{array}{l}\text { Temperature increased, rainfall } \\
\text { decreased and the climate } \\
\text { warmer and drier. }\end{array}$ & $\begin{array}{l}\text { During 1961-2008, the annual mean maximum possible } \\
\text { moisture evaporated amount was } 400-800 \mathrm{~mm} \text { in the Loess } \\
\text { Plateau and was } 650-750 \mathrm{~mm} \text { in most areas. The maximum } \\
\text { possible moisture evaporated amount in the northwest region of } \\
\text { the Loess Plateau increased significantly. }\end{array}$ & $\begin{array}{l}\text { Yao et al. } \\
(2011 d)\end{array}$ \\
\hline & $\begin{array}{l}\text { Rainfall, soil temperature and } \\
\text { soil moisture data during } \\
\text { 1981-2000. }\end{array}$ & $\begin{array}{l}\text { Annual mean temperature increased year } \\
\text { on year by } 0.078^{\circ} \mathrm{C} / \text { year. }\end{array}$ & $\begin{array}{l}\text { Farm soil moisture storage was negatively correlated with } \\
\text { temperature, i.e. farm soil moisture storage decreased as } \\
\text { temperature rose. Because of climate warming, the farm soil } \\
\text { moisture storage in the Loess Plateau of east Gansu decreased } \\
\text { year on year. }\end{array}$ & Ma et al. (2009) \\
\hline & $\begin{array}{l}\text { Rainfall and soil moisture data } \\
\text { during 1981-2000. }\end{array}$ & $\begin{array}{l}\text { Annual mean temperature increased year } \\
\text { on year by } 0.078^{\circ} \mathrm{C} / \text { year. }\end{array}$ & $\begin{array}{l}\text { Farm moisture evaporated transpiration decreased year on year. } \\
\text { Annual farm moisture evaporated and transpiration decreased } \\
\text { by } 157 \mathrm{~mm}(7.86 \%) \text {. }\end{array}$ & $\begin{array}{l}\text { Wang et al. } \\
(2011 \mathrm{a})\end{array}$ \\
\hline & $\begin{array}{l}\text { Meteorological and } \begin{array}{r}\text { soil } \\
\text { moisture data } \\
\text { 1981-2000. }\end{array} \text { during } \\
\end{array}$ & $\begin{array}{l}\text { Annual mean temperature increased and } \\
\text { rainfall decreased year on year. }\end{array}$ & $\begin{array}{l}\text { Soil moisture change was highly correlated with the crop } \\
\text { growing period in the semi-arid area of the Loess Plateau. The } \\
\text { soil moisture in the crop growing period decreased. }\end{array}$ & $\begin{array}{l}\text { Wang et al. } \\
(2005)\end{array}$ \\
\hline & $\begin{array}{l}\text { Positioned observation and } \\
\text { corresponding parallel } \\
\text { meteorological data for winter } \\
\text { wheat grown during 1981-2010. }\end{array}$ & $\begin{array}{l}\text { Annual change in rainfall fluctuated in } \\
\text { years } 3 \text { and } 8 \text {. The annual temperature } \\
\text { increased by } 0.325^{\circ} \mathrm{C} / \text { year. }\end{array}$ & $\begin{array}{l}\text { Winter and spring temperatures in the semi-wet area of the } \\
\text { Loess Plateau increased significantly, the winter death rate of } \\
\text { winter wheat decreased and the moisture utilization rate } \\
\text { increased. }\end{array}$ & $\begin{array}{l}\text { Yao et al. } \\
(2011 b)\end{array}$ \\
\hline & $\begin{array}{l}\text { Rainfall and temperature data } \\
\text { for each month during } \\
1961-2000 \text {. }\end{array}$ & $\begin{array}{l}\text { Temperature increased, rainfall } \\
\text { decreased and drought was more } \\
\text { common. }\end{array}$ & $\begin{array}{l}\text { Soil drought was highly correlated with climate productivity. } \\
\text { Years of soil drought were also years of low climate } \\
\text { productivity, but years of high rainfall were not always years of }\end{array}$ & $\begin{array}{l}\text { Wang et al. } \\
(2004)\end{array}$ \\
\hline
\end{tabular}




\begin{tabular}{|c|c|c|c|c|}
\hline & $\begin{array}{l}\text { Infrared radiator farm warming } \\
\text { simulation experiment. }\end{array}$ & Temperature increased by $0.6-2.5^{\circ} \mathrm{C}$. & $\begin{array}{l}\text { high climate productivity because climate productivity was not } \\
\text { only correlated with moisture but also with temperature and } \\
\text { other factors. } \\
\text { Moisture utilization rate of pea decreased by } 4.3-33.3 \% \text {. }\end{array}$ & $\begin{array}{l}\text { Xiao et al. } \\
(2009)\end{array}$ \\
\hline & \multirow{2}{*}{$\begin{array}{l}\text { Infrared radiator farm warming } \\
\text { and rainfall simulation } \\
\text { experiment. }\end{array}$} & $\begin{array}{l}\text { Rainfall higher than } 310.0 \mathrm{~mm} \text { when } \\
\text { warming was lower than } 1.5^{\circ} \mathrm{C} \text {. }\end{array}$ & Moisture utilization rate of potato increased. & \multirow[t]{2}{*}{$\begin{array}{l}\text { Xiao et al. } \\
(2013)\end{array}$} \\
\hline & & $\begin{array}{l}\text { Rainfall lower than } 310.0 \mathrm{~mm} \text { when } \\
\text { warming was higher than } 1.5^{\circ} \mathrm{C} \text {. }\end{array}$ & Moisture utilization rate of potato decreased. & \\
\hline & $\begin{array}{l}\text { Infrared radiator farm warming } \\
\text { simulation experiment. }\end{array}$ & Temperature increased by $0.5-2.0^{\circ} \mathrm{C}$. & $\begin{array}{l}\text { Moisture utilization rate of a spring wheat-pea-potato crop } \\
\text { rotation system decreased by } 3.0-12.4 \% \text {. }\end{array}$ & 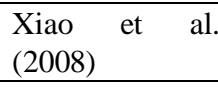 \\
\hline \multirow{6}{*}{ Arid irrigated area } & $\begin{array}{l}\text { Positioned observation data and } \\
\text { meteorological data for soil salt } \\
\text { during 1973-2008. }\end{array}$ & Temperature increased by $0.5 \sim 3.0^{\circ} \mathrm{C}$. & $\begin{array}{l}\text { Soil salt content increased by } 0.03-0.32 \mathrm{~g} / \mathrm{kg} \text {. Irrigation for } \\
\text { scrubbing the increased salt in the soil was } 614-685.3 \mathrm{~m}^{3} / \mathrm{hm}^{2} \\
\text { and the volume of irrigation water needed increased by } \\
8.2-9.1 \% \text {. }\end{array}$ & $\begin{array}{lll}\text { Xiao } & \text { et al. } \\
(2010) & \end{array}$ \\
\hline & $\begin{array}{l}\text { Crop evapotranspiration volume } \\
\text { and meteorological data during } \\
\text { 1959-2007. }\end{array}$ & $\begin{array}{l}\text { Annual mean temperature rose at a } \\
\text { linear rate of } 0.326^{\circ} \mathrm{C} / 10 \text { years, and the } \\
\text { temperature increased by } 1.6^{\circ} \mathrm{C} / \text { year } \\
\text { over } 49 \text { years. Rainfall did not change } \\
\text { significantly. }\end{array}$ & $\begin{array}{l}\text { During } 1959-2007, \text { evapotranspiration volume from the } \\
\text { reference crop decreased by } 61 \mathrm{~mm} / 10 \text { years compared to } 1959, \\
\text { and decreased by } 299.1 \mathrm{~mm} \text { over the past } 49 \text { years. }\end{array}$ & $\begin{array}{l}\text { Zhang } \\
(2009)\end{array}$ \\
\hline & $\begin{array}{l}\text { All data concerning corn were } \\
\text { collected during 1981-2002 } \\
\text { from Wuwei Agricultural } \\
\text { Experimental Station, Gansu, } \\
\text { located in the eastern part of the } \\
\text { Hexi Corridor. }\end{array}$ & $\begin{array}{l}\text { Mean temperature during the corn } \\
\text { growth period was less than the critical } \\
\text { temperature. }\end{array}$ & $\begin{array}{l}\text { Corn moisture utilization rate decreased because of climate } \\
\text { warming. }\end{array}$ & $\begin{array}{lll}\text { Wang } & \text { et } & \text { al. } \\
(2004) & \end{array}$ \\
\hline & $\begin{array}{l}\text { Rainfall, temperature, crop } \\
\text { growing period, yield and soil } \\
\text { moisture data during } \\
\text { 1960-2009. }\end{array}$ & $\begin{array}{l}\text { During 2000-2009, compared with } \\
1960-1969, \text { the annual mean } \\
\text { temperature increased by } 1.6^{\circ} \mathrm{C} \text {, and the } \\
\text { annual mean rainfall decreased by } 105.6 \\
\mathrm{~mm} .\end{array}$ & $\begin{array}{l}\text { Moisture utilization rate of spring wheat decreased by } 0.3-0.5 \\
\mathrm{~kg} / \mathrm{hm}^{2} \mathrm{~mm} \text {. }\end{array}$ & $\begin{array}{l}\text { Xiao et al. } \\
(2011 b)\end{array}$ \\
\hline & England Hadley Model. & $\begin{array}{l}\text { Temperature increased by } 1-4^{\circ} \mathrm{C} \text { during } \\
\text { the crop growing period. }\end{array}$ & $\begin{array}{l}\text { Demand for moisture by corn increased by } 1.90-11.49 \% \text { and by } \\
\text { spring wheat by } 1.80-10.03 \% \text {. Climate warming increased the } \\
\text { sharp conflict between water demand and supply in the green } \\
\text { land of the Hexi Corridor. }\end{array}$ & $\begin{array}{l}\text { Wang et al. } \\
(2011 b)\end{array}$ \\
\hline & $\begin{array}{l}\text { Infrared radiator farm warming } \\
\text { simulation experiment. }\end{array}$ & $\begin{array}{l}\text { Winter temperature increased by } \\
0.5-2.5^{\circ} \mathrm{C} \text {. }\end{array}$ & $\begin{array}{l}\text { Moisture in the soil farming layer decreased from } 18.5 \% \text { to } \\
16.2-12.5 \% \text {. }\end{array}$ & $\begin{array}{l}\text { Xiao et al. } \\
(2012)\end{array}$ \\
\hline
\end{tabular}

APPLIED ECOLOGY AND ENVIRONMENTAL RESEARCH 14(3): 613-636.

http://www.aloki.hu • ISSN 15891623 (Print) • ISSN 17850037 (Online)

DOI: http://dx.doi.org/10.15666/aeer/1403 613636

○ 2016, ALÖKI Kft., Budapest, Hungary 
Table 3. Influence of climate change on crop structure in northwest China

\begin{tabular}{|c|c|c|c|c|c|}
\hline & $\begin{array}{ll}\text { Meteorological } & \text { data/ } \\
\text { simulating experiment }\end{array}$ & Climate change & Yield and quality & Crop structure & Reference \\
\hline \multirow{3}{*}{ Wheat } & $\begin{array}{l}\text { Meteorological data during } \\
1961-2003 \text {. Degree of change } \\
\text { represented by data for } \\
1987-2003 \text { and 1961-1986. The } \\
\text { mean value was calculated from } \\
1971-2000 \text { data. }\end{array}$ & $\begin{array}{l}\text { During 1987-2003, the annual mean } \\
\text { temperature rose significantly as } \\
\text { climate warming increased. }\end{array}$ & $\begin{array}{l}\text { Area planted with spring and winter wheat in } \\
\text { the southwest semi-arid area decreased. }\end{array}$ & $\begin{array}{l}\text { The northern cropping border for } \\
\text { winter wheat in Shaanxi, Inner } \\
\text { Mongolia, Ningxia, Gansu and } \\
\text { Qinghai during 1981-2007 moved } \\
\text { northwards and westwards } \\
\text { compared with 1951-1980. }\end{array}$ & $\begin{array}{l}\text { Liu et al. } \\
(2007)\end{array}$ \\
\hline & $\begin{array}{l}\text { Meteorological data and } \\
\text { positioned observation data for } \\
\text { winter wheat growth during } \\
\text { 1981-2004. Experimental base: } \\
\text { Guyuan. }\end{array}$ & $\begin{array}{l}\text { Annual mean temperature increased } \\
\text { and annual rainfall decreased. }\end{array}$ & $\begin{array}{l}\text { Winter wheat yield was significantly and } \\
\text { positively correlated with the lowest } \\
\text { temperature during the winter period. }\end{array}$ & $\begin{array}{l}\text { In the 1970s, the northern border } \\
\text { of the winter wheat rain-fed } \\
\text { farming area in Ningxia was at } \\
36^{\circ} \mathrm{N} \text {, but has now moved to } 39^{\circ} \mathrm{N} \\
\text { in the Yellow River Irrigation Area. }\end{array}$ & $\begin{array}{l}\text { Zhang et al. } \\
\text { (2008) }\end{array}$ \\
\hline & $\begin{array}{l}\text { Meteorological data and } \\
\text { positioned observation data for } \\
\text { spring wheat and winter wheat } \\
\text { growth during 1981-2005. } \\
\text { Experimental base: Tongwei. }\end{array}$ & $\begin{array}{l}\text { Annual temperature significantly } \\
\text { increased and annual rainfall } \\
\text { decreased. }\end{array}$ & $\begin{array}{l}\text { The harvest ears of spring wheat were highly } \\
\text { reduced, and many seedlings died during the } \\
\text { elongation period. }\end{array}$ & $\begin{array}{l}\text { Spring wheat has been replaced by } \\
\text { winter wheat in the semi-arid } \\
\text { rain-fed farming areas within } \\
34^{\circ} 55^{\prime}-35^{\circ} 26^{\prime} \mathrm{N} \text {. }\end{array}$ & $\begin{array}{l}\text { Xiao et al. } \\
\text { (2007b); } \\
\text { Liu et al. } \\
\text { (2008a) }\end{array}$ \\
\hline \multirow{3}{*}{ Potato } & $\begin{array}{l}\text { Meteorological data and potato } \\
\text { growing data from } 71 \text { stations in } \\
\text { Gansu Province during } \\
\text { 1981-2000. Experimental bases: } \\
\text { Gulang, Dingxi, Beidao and } \\
\text { Pingliang. }\end{array}$ & $\begin{array}{l}\text { Annual mean temperature increased } \\
\text { and annual rainfall decreased. }\end{array}$ & $\begin{array}{l}\text { Potato yields decreased as temperature rose } \\
\text { and increased as rainfall rose. }\end{array}$ & $\begin{array}{l}\text { Potato growing areas have moved } \\
\text { from south to north or from low to } \\
\text { high altitude, and the area has } \\
\text { increased year on year. The highest } \\
\text { altitude suitable for potato in } \\
\text { middle Gansu increased by } \\
100-200 \mathrm{~m} \text { on average. }\end{array}$ & $\begin{array}{l}\text { Yao et al. } \\
(2006)\end{array}$ \\
\hline & 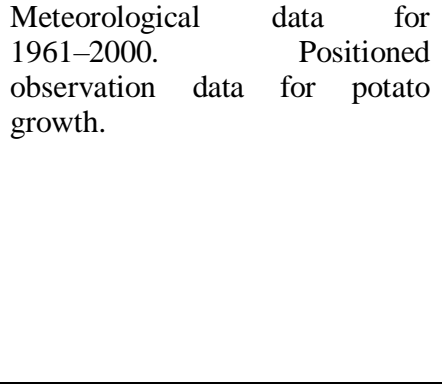 & $\begin{array}{l}\text { Annual mean temperature increased } \\
\text { by } 0.026^{\circ} \mathrm{C} / \text { year. Rainfall decreased. }\end{array}$ & $\begin{array}{l}\text { The main meteorological factors influencing } \\
\text { potato yield were temperature in the tuber } \\
\text { expansion period (mean temperature in } \\
\text { July-August) and rainfall over the whole } \\
\text { growing period (May-September). There was } \\
\text { not much demand for moisture during the } \\
\text { early and later periods of potato growth. } \\
\text { Demand for water was greatest in the } \\
\text { blooming period and this period coincided } \\
\text { with the main rainfall period in the Loess } \\
\text { Plateau. }\end{array}$ & $\begin{array}{l}\text { Climate warming in the Loess } \\
\text { Plateau is both advantageous and } \\
\text { disadvantageous for potato } \\
\text { production. }\end{array}$ & $\begin{array}{l}\text { Song } \\
(2008)\end{array}$ \\
\hline & $\begin{array}{l}\text { Meteorological data for } \\
\text { 1961-2000. Potato yield data for } \\
\text { 1971-2000. }\end{array}$ & $\begin{array}{l}\text { Over the past } 40 \text { years in the } \\
\text { Ningnan mountainous area, annual } \\
\text { mean temperature increased and }\end{array}$ & & $\begin{array}{l}\text { Over the past } 40 \text { years, the climate } \\
\text { in Ningxia has become warmer and } \\
\text { drier. Climate factors influencing }\end{array}$ & $\begin{array}{l}\text { Sun et al. } \\
(2008)\end{array}$ \\
\hline
\end{tabular}




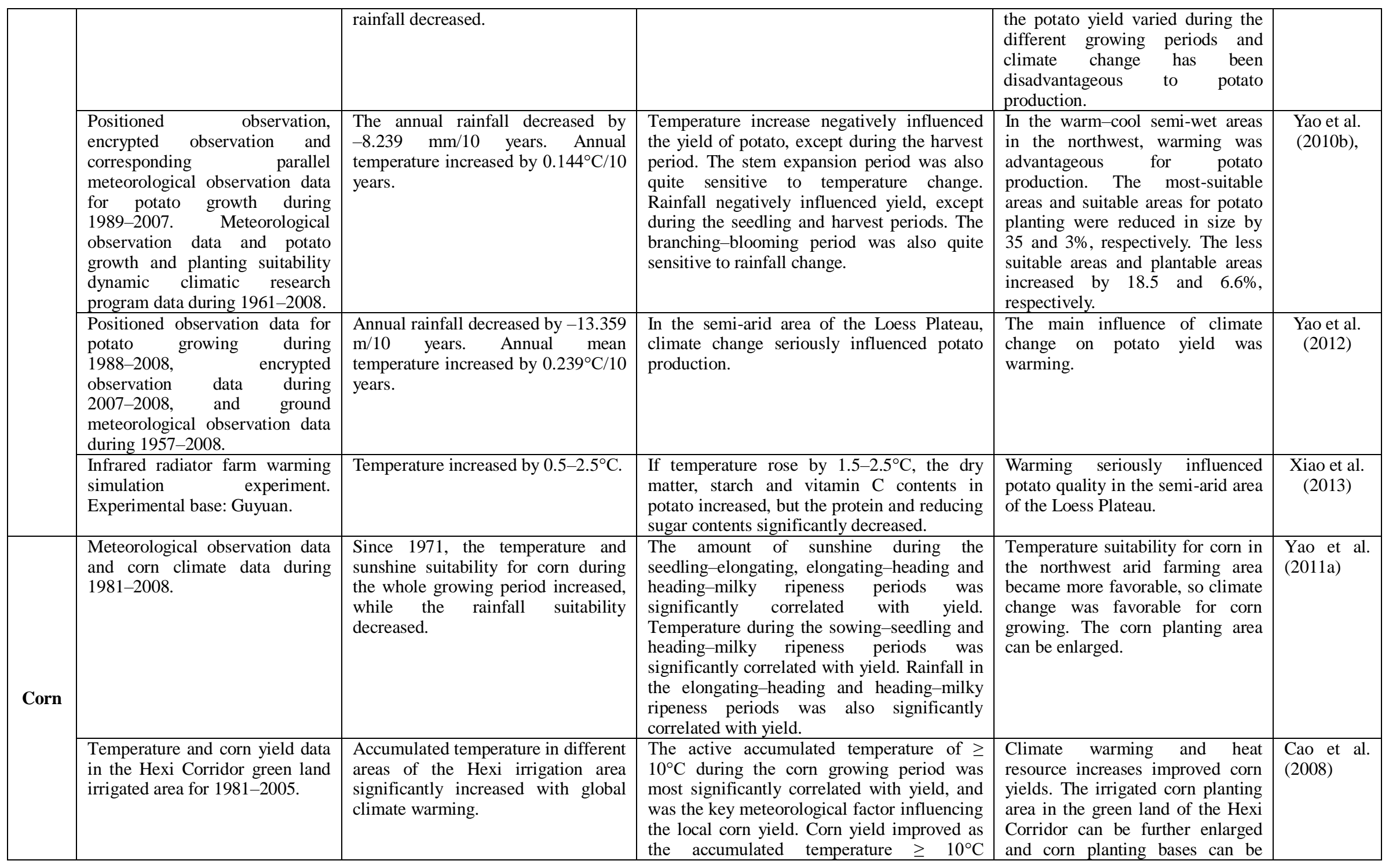

APPLIED ECOLOGY AND ENVIRONMENTAL RESEARCH 14(3): 613-636.

http://www.aloki.hu • ISSN 15891623 (Print) • ISSN 17850037 (Online)

DOI: http://dx.doi.org/10.15666/aeer/1403 613636

(๖) 2016, ALÖKI Kft., Budapest, Hungary 


\begin{tabular}{|c|c|c|c|c|}
\hline & & increased. & $\begin{array}{l}\text { constructed. The corn planting area } \\
\text { expanded from south to north. }\end{array}$ & \\
\hline $\begin{array}{l}\text { Degree of change represented by } \\
\text { data during 1987-2003 and } \\
\text { 1961-1986. Mean value during } \\
\text { 1971-2000. }\end{array}$ & $\begin{array}{l}\text { Annual mean temperatures rose } \\
\text { sharply as climate warming } \\
\text { increased. }\end{array}$ & $\begin{array}{l}\text { The corn planting area significantly rose } \\
\text { because of climate warming, temperature } \\
\text { rises and heat resource increases. The } \\
\text { structure of summer and autumn crops } \\
\text { changed significantly. }\end{array}$ & $\begin{array}{l}\text { Corn planting area in the southwest } \\
\text { arid area had sharply increased. }\end{array}$ & $\begin{array}{l}\text { Liu et al. } \\
(2009)\end{array}$ \\
\hline $\begin{array}{l}\text { All the data concerning corn } \\
\text { were collected during 1981-2002 } \\
\text { from Wuwei Agricultural } \\
\text { Experimental Station in Gansu, } \\
\text { located in the eastern part of the } \\
\text { Hexi Corridor. }\end{array}$ & $\begin{array}{l}\text { Mean temperature during the corn } \\
\text { growth period was less than the } \\
\text { critical temperature. }\end{array}$ & $\begin{array}{l}\text { Corn yield in the semi-arid rain-fed farming } \\
\text { area decreased by } 3 \% \text { for every } 1^{\circ} \mathrm{C} \\
\text { temperature rise. }\end{array}$ & $\begin{array}{l}\text { Future increases in temperature } \\
\text { may cause the mean temperature } \\
\text { during the corn growth period to } \\
\text { exceed the critical temperature, } \\
\text { thus leading to a lengthening of the } \\
\text { growth period. }\end{array}$ & $\begin{array}{l}\text { Wang et al. } \\
(2004)\end{array}$ \\
\hline $\begin{array}{l}\text { Meteorological data and corn } \\
\text { climate data during 1961-2009. }\end{array}$ & $\begin{array}{l}\text { Annual mean temperature increased } \\
\text { significantly by } 0.37^{\circ} \mathrm{C} / 10 \text { years. The } \\
\text { annual rainfall decreased by } 3.70 \\
\text { mm/10 years. }\end{array}$ & $\begin{array}{l}\text { Warming directly influenced the } \\
\text { photosynthesis rate and respiration rate, } \\
\text { which affected the accumulation of dry matter } \\
\text { and reduced crop quality. }\end{array}$ & $\begin{array}{l}\text { In the plateau area of Qinghai } \\
\text { (Xining and Ledu), the climate } \\
\text { became warmer, the heat resource } \\
\text { significantly increased and the } \\
\text { crop plant structure and planting } \\
\text { area changed significantly. }\end{array}$ & $\begin{array}{l}\text { Liu et al. } \\
(2007)\end{array}$ \\
\hline $\begin{array}{l}\text { Change in mean temperature, } \\
\text { highest temperature, lowest } \\
\text { temperature and effective } \\
\text { temperature accumulated at } \geq \\
10^{\circ} \mathrm{C} \text { in the corn growing period } \\
\text { during the } 2020 \mathrm{~s}, 2050 \mathrm{~s} \text { and } \\
2080 \mathrm{~s} \text {. }\end{array}$ & $\begin{array}{l}\text { Future highest temperatures will } \\
\text { sharply increase in south Ningxia; } \\
\text { the mean temperature, lowest } \\
\text { temperature and effective } \\
\text { temperature accumulated at } \geq 10^{\circ} \mathrm{C} \\
\text { will sharply increase in north } \\
\text { Ningxia. }\end{array}$ & $\begin{array}{l}\text { Future temperature rises will promote corn } \\
\text { production in Ningxia, and the extra effective } \\
\text { temperature accumulated at } \geq 10^{\circ} \mathrm{C} \text { will } \\
\text { provide more heat. }\end{array}$ & $\begin{array}{l}\text { Altitude of suitable planting areas } \\
\text { for corn in the south mountainous } \\
\text { area of Ningxia will rise by } 150 \mathrm{~m} \text {. }\end{array}$ & Gou (2012) \\
\hline $\begin{array}{l}\text { Analysis of temperatures at } 10 \\
\text { observation stations in the } \\
\text { Ningxia Yellow River Irrigation } \\
\text { Area for the corn growing } \\
\text { period, starting in the last } 10 \mathrm{~d} \text { of } \\
\text { April and ending in the middle } \\
10 \mathrm{~d} \text { of September, during } \\
1981-2004 \text {. }\end{array}$ & $\begin{array}{l}\text { Climate in the Ningxia Yellow River } \\
\text { Irrigation Area during the corn } \\
\text { growing period became significantly } \\
\text { warmer. A sharp change in daily } \\
\text { mean temperature during } \\
\text { May-September happened in } 1993 \text {, } \\
\text { and temperature increased by } 0.7^{\circ} \mathrm{C} \text {. }\end{array}$ & & $\begin{array}{l}\text { Climate warming has meant that } \\
\text { high yielding varieties can be } \\
\text { planted, the variation in corn yield } \\
\text { per unit area decreased and ensured } \\
\text { stable high yields. }\end{array}$ & $\begin{array}{l}\text { Liu et al. } \\
(2008 \text { b) }\end{array}$ \\
\hline
\end{tabular}




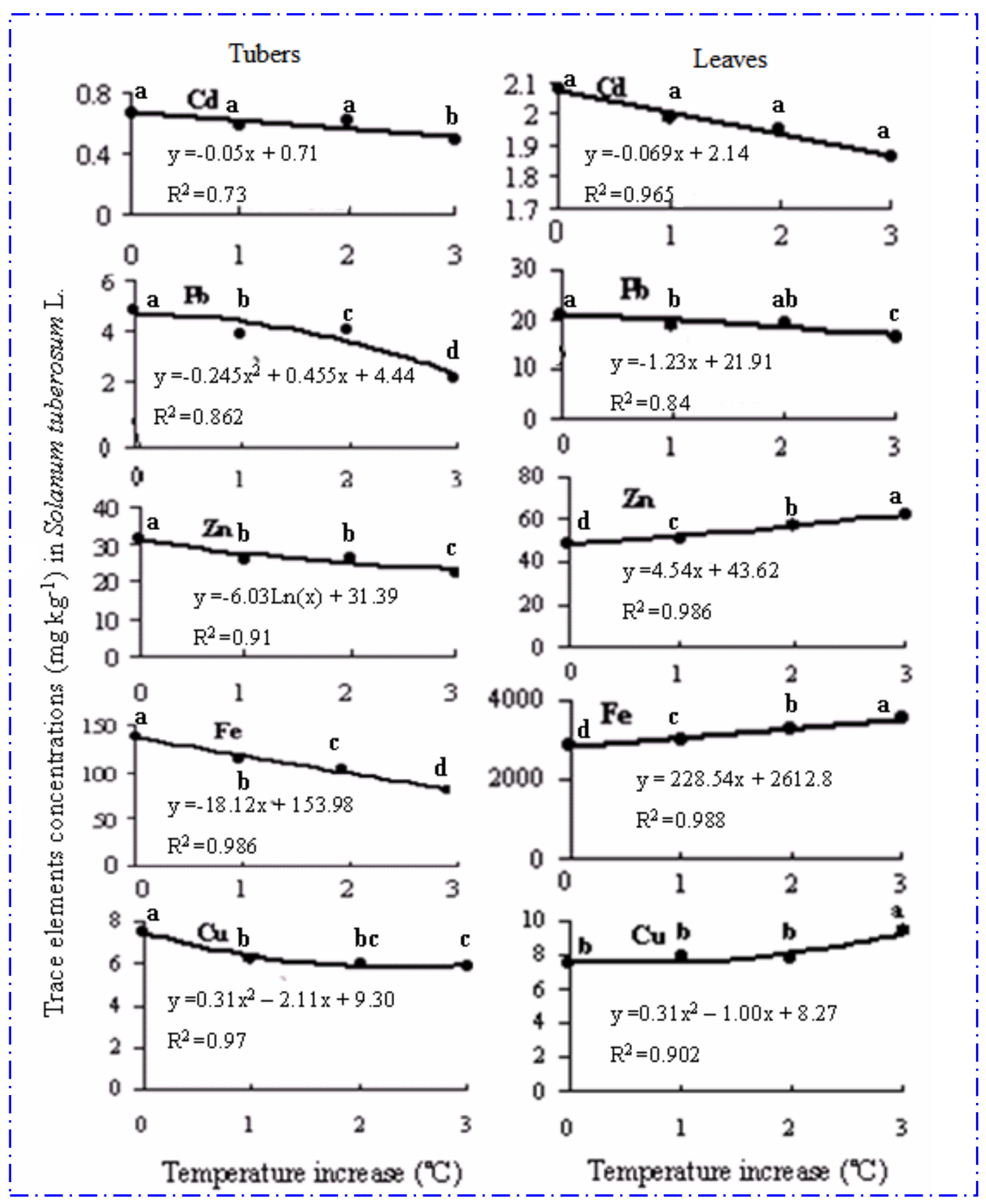

Figure 3. Relationship between trace element concentrations $(\mathrm{mg} / \mathrm{kg})$ in potato and temperature increase in two different tissues (tubers and leaves).

Different letters indicate significant differences between treatments $(p<0.05$, post-hoc Bonferroni-Dunn test, ANOVA). A simulated warming experiment was conducted to evaluate the effects of temperature increase on $\mathrm{Cd}, \mathrm{Pb}, \mathrm{Cu}$, iron ( $\mathrm{Fe}$ ) and $\mathrm{Zn}$ accumulation in potato at Dingxi, Gansu, in semi-arid Northwest China. The aim of this study was to determine if temperature increases significantly changed trace element concentrations and contents in the different ecosystem compartments by affecting soil content, soil solubility and plant capture. The results revealed that an increase in temperature led to a significant change in trace element concentrations and contents in potato. The strongest effects of a $3^{\circ} \mathrm{C}$ temperature 
increase were a rise in $\mathrm{Cu}, \mathrm{Zn}$ and Fe leaf concentrations of 25, 27 and 24\%, respectively; but decreases in $\mathrm{Cd}, \mathrm{Pb}, \mathrm{Fe}, \mathrm{Zn}$ and $\mathrm{Cu}$ tuber concentrations of 27, 55, 41, 29 and 23\%, respectively. The increasing concentrations of some trace elements in potato leaves were related to greater retranslocation, photosynthetic capacity and growth. Warming decreased the concentrations of some trace elements in tubers, implying that tuber growth rate exceeded its metal uptake rate at higher temperatures. It is expected that by the year 2050, the increased temperatures will have caused a decrease in the concentrations of $C d$, $\mathrm{Pb}, \mathrm{Cu}, \mathrm{Fe}$ and $\mathrm{Zn}$ of 9.1, 11.5, 18.5, 16.8 and 15.8\%, respectively, in tubers in the study area. In addition, the results indicated that a $1-3^{\circ} \mathrm{C}$ increase in temperature will improve the availability of selected trace elements and the transfer potential of these elements from soil to potato (Li et al, 2012).

\section{Threat to food nutrition}

Changes in temperature, drought and rainfall modify the inputs of chemical fertilizer and pesticides, degrade soil quality and increase crop pest problems (Zhang et al., 2015a). Climate warming also modifies the absorption of trace and heavy metal elements and causes a lack of nutrients and excessive uptake of toxic elements, such as aluminum and $\mathrm{Mn}$. This decreases the distributed proportions of photosynthetic products in stems, leaves and fruits and directly reduces food nutritional value ( $\mathrm{Lu}$ et al., 2015). It is estimated that if temperature rises by $1^{\circ} \mathrm{C}$, the starch content in spring wheat in Northwest China will decrease by $1.6 \%$ and protein content will increase by $0.8 \%$ (Li et al., 2011). If the temperature rises by $1.5-2.5^{\circ} \mathrm{C}$, the dry matter, starch and vitamin $\mathrm{C}$ contents in potato will increase, but the content of protein and reducing sugars will significantly decrease (Fig. 4). High temperatures and dry hot winds will increase the spread of pests and threaten food security.

\section{Increased crop yield fluctuations}

Climate warming will modify the physiology and ecology of crops in Northwest China, accelerate crop growth and seriously affect crop yield (Chen et al., 2015). During 1980-2010, the yield of spring wheat in Northwest China was generally reduced by climate warming and the size of the yield reduction was larger in the rain-fed than the irrigated farming area. If the temperature increases by $1{ }^{\circ} \mathrm{C}$, the yield of spring wheat in semi-arid rain-fed farming areas will fall by $15-30 \%$ and the yield of corn will fall by $3 \%$ (Wang, 2009). In the semi-arid rain-fed area of Tongwei and Dingxi, within $34^{\circ} 55^{\prime}-35^{\circ} 26^{\prime}$, spring wheat has been replaced by winter wheat in recent years and pea is no longer grown (Xiao et al., 2008). If temperature rises by $0.5-2.5^{\circ} \mathrm{C}$, the yield of spring wheat will decrease by $16.5-18.5 \%$. If temperature rises by $0.6-2.2^{\circ} \mathrm{C}$, the yield of pea in the rain-fed farming area will decrease by $6.3-17.5 \%$ and if the rise is $0.5-2.0^{\circ} \mathrm{C}$, the yield of pea-spring wheat-potato rotation crops will decrease by 3.2-9.4\% (Xiao et al., 2009). It is estimated that over the next 50 years, the threat to grain security in the arid and semi-arid areas of Northwest China will significantly increase. 


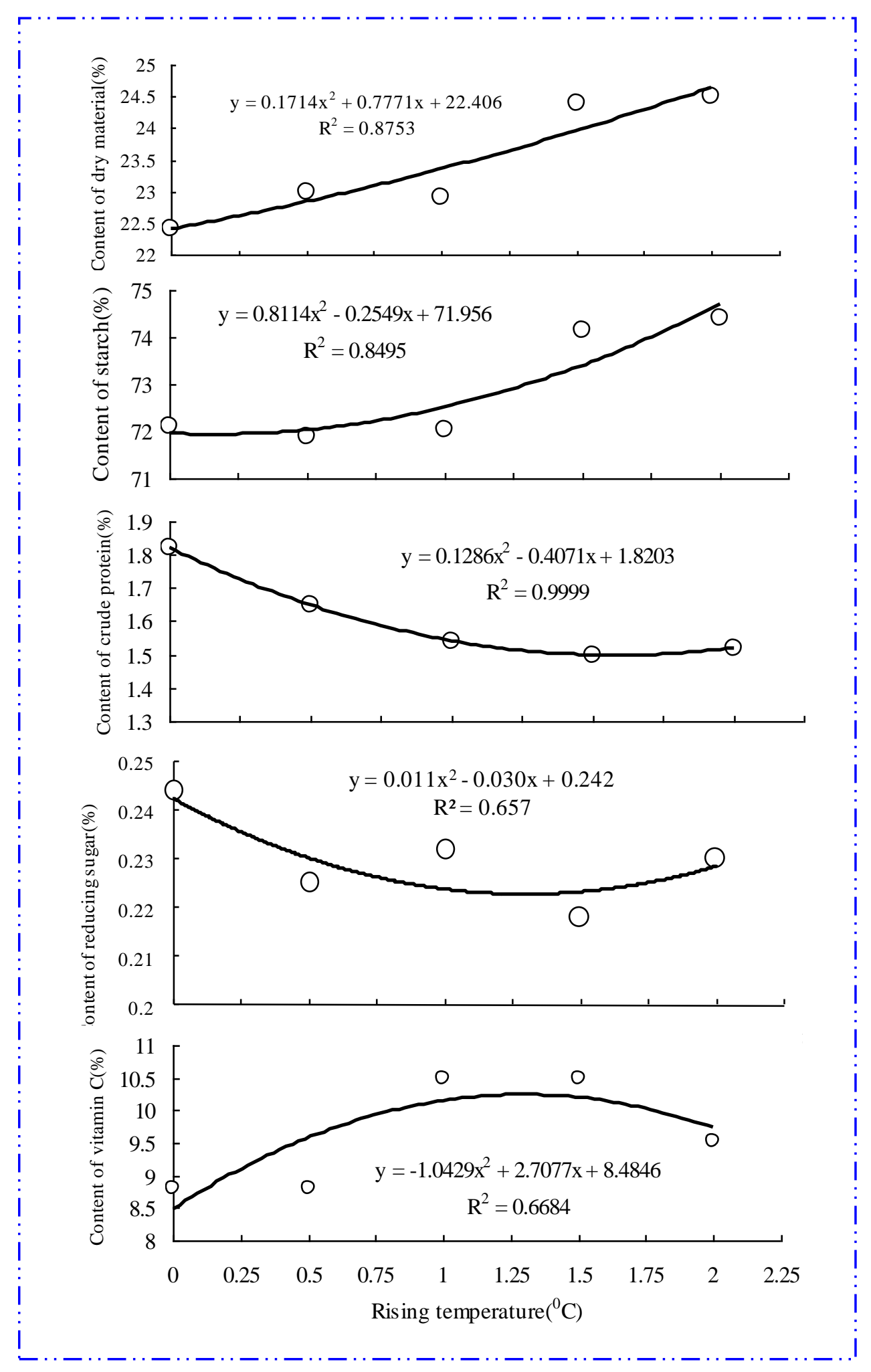

Figure 4. Impact of rising temperature on the main component content of the potato blocks. This experimental study on simulated farm warming using infrared radiators showed that as temperature increased, the dry material and starch content in potato tubers rose significantly, but crude protein and reducing sugar content significantly decreased. Vitamin $C$ first increased and then declined. When temperature increased by $0.5-2.0^{\circ} \mathrm{C}$, the dry material content in potato increased from 22.4 to $24.5 \%$, and 
starch content increased from 72.1 to $74.4 \%$, suggesting that warming favored the accumulation of dry material and starch in potato. When temperature increased by $0.5-2.0^{\circ} \mathrm{C}$, the crude protein content in potato decreased from 1.82 to $1.52 \%$ and the reducing sugar content decreased from 0.24 to $0.22 \%$, showing that warming negative affected crude protein and reducing sugar contents. When temperature increased by $<1.5^{\circ} \mathrm{C}$, the vitamin $C$ content in potato increased; however, when temperature increased by $>1.5^{\circ} \mathrm{C}$, it decreased. Thus, warming also had an unfavorable influence on vitamin C content (Xiao et al, 2013).

\section{Increased investment in grain production}

Climate warming decreases soil fertility, and so demand for fertile land for growing crops will increase. Climate warming will increase soil moisture evaporation and plant transpiration and so a greater water resources will be needed (Liu and Cui, 2011). It will also increase salinity and high $\mathrm{pH}$ damage to the soil farming layer and create difficulties when trying to improve saline and high $\mathrm{pH}$ soils. Finally, climate warming will greatly increase the risk index of pests during the crop growing period, especially in spring. All these factors mean that climate warming will significantly increase the cost of grain production (Zhang et al., 2015b).

\section{Conclusion and outlook}

The development of high thermal requirements, high yield potential and heat-tolerant crop varieties, together with improvements in agronomic management, should be encouraged to meet the challenges of climate change and increasing food demand in future. Taking scientific measures to actively keep pace with climate change will be a key strategy for reducing the risk to grain security in Northwest China. To this end, these regions need to implement crop planting structure strategies, such as 'Winter Wheat Northward', 'Compression of Summer Crop Planting and Expansion of Autumn Crop Planting' and 'Multiple Cropping' to promote the adjustment of agricultural structure and cropping systems needed to enhance the level of food production. There is a need to actively promote study of the impact of climate change on food security to be able to provide an accurate scientific basis for responding to food security threats. Priority needs to be given to water since the stability of ecosystems will be reduced by global climate change and this will exacerbate the complexity of water resource problems (Xiao et al., 2007a; Zhang et al., 2015c). Drought disaster events in northwestern regions have occurred more frequently and the severity of hail, thunderstorms, violent floods and dry, hot winds has increased. It is essential to establish prediction and warning technology for extreme weather events in order to enhance the ability to respond to such events and reduce the impact of future natural disasters (Yang et al., 2015).

Acknowledgements. This work was supported by the National Key Research and Development (973) Program of China (2013CB430206), the National Public Benefit Meteorological Research Program (GYHY201506001, GYHY201106029 and GYHY200806021), the Young Teacher Training Program of Ningxia Hui Autonomous Region (NGY2015055), the National Natural Science Fund (41165009, 
40830957, 40575006 and 40775057), the National Key Scientific Research Program (2012CB955304), the National Technological Problem Tackling Program (2004BA901A16), the National Ministry of Science and Technology Scientific Research Institute Public Benefit Research Program (2000DIA0031, 2004DIB5J192 and 2005DIB3J100) and the Gansu Scientific and Technological Problem Tackling Program (2GS042-A44-017 and GS012-A45-118).

\section{REFERENCES}

[1] Cao, L., Deng, Z., Dou, Y., Yang, X. (2008): Influence of Climate Warming on Corn Output in Hexi Corridor Oasis Irrigation Area and Its Countermeasure Research. - Acta Bot. Boreal. Occident. Sin. 28(5): 1043-1048.

[2] Chang, J. X., Wang, Y. M., Istanbulluoglu, E., Bai, T., Huang, Q., Yang, D. W., Huang, S. Z. (2015): Impact of climate change and human activities on runoff in the Weihe River Basin, China. - Quaternary International 380: 169-179.

[3] Chen, C., Zhou, G. S., Pang, Y. M. (2015): Impacts of climate change on maize and winter wheat yields in China from 1961 to 2010 based on provincial data. - Journal of Agricultural Science 153(5): 825-836.

[4] Dai, A. (2011): Drought under global warming: areview. - Climatic Change 2:45-65.

[5] Deng, Z., Zhang, Q., Wang, Q., Wang, R., Wang, J., Wang, H., Xu, J. (2010): Effects of soil water storage capacity and consumption on winter wheat water use efficiency in dry land areas of the Loess Plateau in western China. - Acta Ecologica Sinica 30(4): 3672-3678.

[6] Deng, Z., Zhang, Q., Wang, R., Zhao, H., Xu, J., Liu, M., Zhao, H., Yao, Y. (2012): The Response of plant diseases and pests to climatic warmer-drying and its adaptive technique in the Northwest China. - Advances in Earth Science 27(1): 1281-1287.

[7] Du, L., Li, Y., Wang, Z. (2011): Analysis on Response of the Winter Wheat Growth to Global Climate Change in Northwest China. - Journal of Shanxi Agricultural Sciences 39(8): 872- 876.

[8] Gao, L., Zhang, Y. N. (2016): Spatio-temporal variation of hydrological drought under climate change during the period 1960-2013 in the Hexi Corridor, China. - Journal of Arid Land 8(2): 157-171.

[9] Gao, M., Fan, J., Wu, Q., Jing, Y. (2012): The change of climate and climate productivity in Weibei plateau under global climate change. - Agricultural Research in the Arid Areas 30(4): 178-183.

[10] Gou, S., Zhang, Y., Xu, Y. (2012): Analysis of climate resource changes during maize growth period in Ningxia under SRES A1B scenario. - Chinese Journal of Eco-Agriculture 20(10):1394-1403.

[11] Ponce-Campos, G. E., Moran, M. S., Huete, A., Zhang, Y., Bresloff, C., Huxman, T. E., Eamus, D., Bosch, D. D., Buda, A. R., Gunter, S. A., Scalley, T. H., Kitchen, S. G., McClaran, M. P., McNab, W. H., Montoya, D. S., Morgan, J. A., Peters, D. P. C., Sadler, E. J., Seyfried, M. S., Starks, P. J. (2013): Ecosystem resilience despite large-scale altered hydroclimatic conditions. - Nature 470(1):1-4.

[12] Hou, Q., Guo, R., Yang, L. (2009): Climate Change and Its Impact on Main Crops in Inner Mongolia. - Chinese Journal of Agrometeorology 30(4): 560-564

[13] Lei, Y. D., Zhang, H. L., Chen, F., Zhang, L. B. (2016): How rural land use management facilitates drought risk adaptation in a changing climate, A case study in arid northern China. - Science of the total Environment 550: 192-199. 
[14] Leng, G. Y., Tang, Q. H., Rayburg, S. (2015): Climate change impacts on meteorological, agricultural and hydrological droughts in China. - Global and Planetary Change 126: 23-34.

[15] Li, J-P., Yang, K., Cao, N., Han, Y-J., Zhang, X-Y. (2009): Simulation of Changes of Potato Yields under Different Climate Change Scenarios in Ningxia. - Chinese Journal of Agrometeorology 30(3): 407-412.

[16] Li, Y., Li, L., Zhang, Q., Yang, Y., Wang, H., Wang, R., Zhang, J. (2013): Influence of temperature on the heavy metals accumulation of five vegetable species in semiarid area of northwest China. - Chemistry and Ecology 29(4): 353-365.

[17] Li, Y., Zhang, Q., Wang, R., Gou, X., Wang, H., Wang, S. (2012): Temperature changes the dynamics of trace element accumulation in Solanum tuberosum L. - Change 112(3): 655-672.

[18] Li, Y., Zhang, Q., Wang, R., Liu, N., Xiao, G., Gou, X., Ma, Z. (2011): Influence of climatic warming on accumulation of trace elements in spring wheat. - Transactions of the CSAE 27(12): 96-104.

[19] Liu, D., Dong, A., Liang, D., Ning, H. (2007): Affect of Climate Warming on Crops Planting Structure in Arid Zone of Northwestern China. - Journal of Desert Research 27(5): 831-83. 。

[20] Liu, M., Jiang, J., Shi, Z. (2009): Meteorological impact factors and forecast of wheat aphid population dynamic changes. - Journal of Agrometeorology 30( 3):440-444.

[21] Liu, Q. A., Cui, B. S. (2011): Impacts of climate change/variability on the streamflow in the Yellow River Basin, China. - Ecological Modelling 222(2): 268-274.

[22] Liu, Y., Zhang, X., Liu, J., Kang, Y. (2008a): Impact of Climate Change on Spring Wheat Yield in Yellow River Irrigation Region of Ningxia. - Advances in Climate Chang Research 4(2):90-94. 。

[23] Liu, Y., Zhang, X., Liu, J., Kang, Y. (2008b): Impact of Climate Warming on Maize Yield In Irrigation Area of Ningxia. - Journal of Maize Sciences 16(2):147-149. 。

[24] Lu, Y. L., Chadwick, D., Nors, D., Powlsond, D., Shi, W. M. (2015): Sustainable intensification of China's agriculture: the key role of nutrient management and climate change mitigation and adaptation. - Agriculture, Ecosystems \& Environment 209(SI): $1-4$.

[25] Saleska, S. R., Didan, K., Huete, A. R., da Rocha, H. R. (2007): Amazon forests green-up during 2005 drought. - Science 318: 612.

[26] Piao, S., Ciais, P., Huang, Y., Shen, Z., Peng, S., Li, J., Zhou, L., Liu, H., Ma, Y., Ding, Y., Friedlingstein, P., Liu, C., Tan, K., Yu, Y., Zhang, T., Fang, J. (2010): The impacts of climate change on water resources and agriculture in China. - Nature 467(2): 42-51.

[27] Song, Q., Qian, H., Lai, C. (2008): Research progress on the vulnerability evaluation of agricultural climate changes. - Journal of Anhui Agricultural Sciences 36(24): 9646-9649.

[28] Sun, F., Lin, E.,Wu, Y. (2008): Climate Change and Its Impacts on Potato Production in Ningxia. - Chinese Agricultural Science Bulletin 24(4):465-471.

[29] Tollefson, J. (2015): Climate change China backs cap-and-trade. - Nature 526(7571): 13-14.

[30] Wang, H. L., Gan, Y. T., Wang, R. Y. (2008): Phonological trends in winter wheat and spring cotton in response to climate changes in northwest China. - Agricultural and Forest Meteorology 148: 1242-1251.

[31] Wang, H., Niu, J., Wang, R., Lu, X. (2011a): Impact of climate change on water requirement of main crops in irrigated oasis of Hexi corridor. - Acta Prataculturae Sinica 
20(5): 245-251.

[32] Wang, L., Li, F., Xu, W., Li, X., Su, W. (2011b): Climate Warming Impacts on Spring Wheat Growth at Different Altitude Regions in Qinghai Plateau. - Adv. Clim. Change Res. 7(5): 324-329.

[33] Wang, N., Zhang, M., Huang, B., Ma, C. (2009): Relationship Discussion between Soil Moisture Change with Maize Yield in East of Gansu Province. - Chinese Agricultural Science Bulletin 25(21): 320-323.

[34] Wang, R., Zhang, Q., Wang, Y. (2004): Response of Corn to Climate Warming in Arid Areas in Northwest China. - Acta Botanica Sinica 46 (12):1387-1392.

[35] Wang, Y-R., Yao, Y-B. (2005): Dynamics of Soil Moisture in Gansu Loess. - Chinese Journal of Soil Science 36(3):850-855.

[36] Xiao, G., Zhang, Q., Zhang, F., Luo, C., Wang, R. (2011a): The impact of rising temperature on spring wheat production in the Yellow River irrigation region of Ningxia. - Acta Ecologica Sinica 31(21): 6588-6593.

[37] Xiao, G., Zhang, F., Qiu, Z., Yao, Y., Wang, R., Huang, J. (2013): Response to climate change for potato water use efficiency insemi-arid areas of China. - Agricultural Water Management 127: 119-123.

[38] Xiao, G., Zhang, Q., Bi, J., Zhang, F., Luo, C. (2012): The Relationship Between Winter Temperature Rise and Soil Fertility Properties. - Air, Soil and Water Research 5: 15-22.

[39] Xiao, G., Zhang, Q., Li, Y., Zhang, F., Wang, R., Luo, C. (2010): Impact of climatic warming on soil salinity and irrigation amount of Yellow River irrigation areas in Ningxia Hui Autonomous Region. - Transactions of the CSAE 26(6): 7-13.

[40] Xiao, G., Zhang, Q., Li, Yu (2011b): Effect of winter warming on soil moisture and salinization. - Transactions of the CSAE 27(8): 46-51.

[41] Xiao, G., Zhang, Q., Wang, R., Yao, Y., Zhao, H., Bai, H., Xiong, Y. (2009): Effects of temperature increase on pea production in a semiarid region of China. - Air, Soil and Water Research 2: 31-39.

[42] Xiao, G., Zhang, Q., Xiong, Y., Lin, M., Wang, J. (2007a): Integrating rainwater harvesting with supplemental irrigation into rain-fed spring wheat farming. - Soil \& Tillage Research 93: 429-437.

[43] Xiao, G., Zhang, Q., Xiong, Y., Yang, X., Yang, Q., Sun, Z. (2007b): Effects of temperature increase on water use and total yields of crops in a pea-spring wheat-potato rotation system in semiarid regions of China. - Agricultural Water Management 91: 86-91.

[44] Xiao, G., Zhang, Q., Yao, Y., Zhao, H., Wang, R., Bai, H., Zhang, F. (2008): Impacts of recent climatic change on the yields of winter wheat at different altitudes above sea level in semi-arid northwestern China. - Agriculture, Ecosystems \& Environment 127: 37-42.

[45] Yang, Q., Chen, X., Xu, Y., Lin, E., Xiong, W. (2009): Response Simulation of Spring Wheat in Ningxia Region to Climate Change Scenario. - Journal of Triticeae Crops 29(3):491-496. 。

[46] Yang, S., Mu, W., Xiao, G. (2010): The Temperature Change and Its Influences on Agricultural Production in Weibei Dry land. - Chinese Agricultural Science Bulletin 26(15): 109-114.

[47] Yang, X. G., Chen, F., Lin, X. M., Liu, Z. J., Zhang, H. L., Zhao, J., Li, K. N., Ye, Q., Li, Y., Lv, S. (2015): Potential benefits of climate change for crop productivity in China. Agricultural and Forest Meteorology 208: 76-84.

[48] Yao, X., Pu, J., Yao, R., Jia, H., Ma, J. (2011a): Variation of Climate Suitability of Maize 
in Arid Area in Gansu under the Condition of Climate Dry-warming. - Acta Geographica Sinica 66(1):59-70.

[49] Yao, Y. B., Wang, R. Y., Yang, J. H., Xiao, G. J., Zhang, X. Y. (2011b): Impacts of climatic change on spring wheat growth in a semi-arid region of the Loess Plateau: a case study in Dingxi, Gansu Province. - Acta Ecologica Sinica 31(15): 4225-4234.

[50] Yao, Y., Deng, Z., Wang, R., Wang, Y., Pu, J., Zhang, X. (2006): The influence of climate changes on potato growth in Gansu province. - Agricultural Research in the Arid Areas 24(3): 16-24.

[51] Yao, Y., Wang, R., Deng, Z., Han, S., Xing, T. (2010a): Effects of climate change on potato growth in semi-arid region of Loess Plateau, China. - Chinese Journal of Applied Ecology 21(2):287-295.

[52] Yao, Y., Wang, R., Yang, J., Xiao, G., Zhang, X. (2011c): Impacts of climatic change on spring wheat growth in a semi-arid region of the Loess Plateau: a case study in Dingxi, Gansu Province. - Acta Ecologica Sinica 31(15):4225-4234.

[53] Yao, Y., Wang, R.,Yang, J., Yue, P., Lu, D., Xiao, G., Wang, Y., Liu, L. (2011c): Change of terrestrial surface potential evapotranspiration in Loess Plateau. - Ecology and Environment 20(8-9): 1189-1195.

[54] Yao, Y., Zhang, X., Wang, R., Deng, Z., Lu, H. (2010b): Impacts of climatic change on potato growth in the semi-humid region over extra-tropical and cool Northwest of China: a case study in Minxian County of Gansu Province. - Acta Ecologica Sinica 30( 1):0100-0108.

[55] Yao, Y., Wang, R., Yang, J., Zhang, M., Yue, P., Xiao, G. (2012): Impacts of climate change on growth and yield of winter wheat in the semi-humid region of the Loess Plateau. - Acta Ecologica Sinica 32(16):5154-5163.

[56] Yao, Y., Zhang, X., Lu, H., Han, H., Li, X., Zhang, S. (2009): Influence of Meteorological Conditions on Potato Tuber Formation and Yield in Temperate and Cooi Semi-humid Regions of Northwest China. - Chinese Journal of Agrometeorology 30(2):208-211.

[57] Ye, J-B., Xiao, Z-L., Li, C-H., Wang, F-S., Liao, J-C., Fu, J-Z., Zhang, Z-B. (2015): Past climate change and recent anthropogenic activities affect genetic structure and population demography of the greater long-tailed hamster in northern China. - Integrative Zoology 10(5): 482-496.

[58] Zhang, C., Lai, S-Y., Gao, X- P., Xu, L- P. (2015a): Potential impacts of climate change on water quality in a shallow reservoir in China. - Environmental Science and Pollution Research 22(19): 14971-14982.

[59] Zhang, H-L., Zhao, X., Yin, X-G., Liu, S-L., Xue, J-F., Wang, M., Pu, C., Lal, R., Chen, F. (2015b): Challenges and adaptations of farming to climate change in the North China Plain. - Climatic Change 129: 213-224.

[60] Zhang, J., Li, Y. (2001): Three climatic stages of cotton bollworm living through winter in Xinjiang. - Journal of Agrometeorology 22(1):43-46.

[61] Zhang, Q., Deng, Z-Y., Zhao, Y-D., Qiao, J. (2008): The impacts of global climatic change on the agriculture in northwest China. - Acta Ecologica Sinica 28(3): 1210-1218.

[62] Zhang, Q., Zhang, C., Bai, H., Li, L., Sun, L., Liu, D., Wang, J., Zhao, H. (2010): New Development of Climate Change in Northwest China and Its Impact on Arid Environment. - Journal of AridMeteorology 28-1:1-7.

[63] Zhang, S., Pu, Z., Song, L., Zhou, H., Song, S. (2009): Effect of Climate Change on Potential Evapotranspiration in Turpan Region. - Chinese Journal of Agrometeorology 30 
(4): $532-537$.

[64] Zhang, Y-Y., Fu, G-B., Sun, B-Y., Zhang, S- F., Men, B-H. (2015c): Simulation and classification of the impacts of projected climate change on flow regimes in the arid Hexi Corridor of Northwest China. - Journal of Geophysical Research-Atmospheres 120(15):7429-7453.

[65] Zhang, Z., Lin, L., Liang, P. (2008): Climate Change and its Impacts on Agricultural Production in Ningxia. - Chinese Journal of Agrometeorology 29(4):402-405.

[66] Zhao, H., Wang, R-Y., Wang, H., Yang, Q., Deng, Z-Y., Xiao, G. (2007a): Regional Diversity in Response of Spring Wheat Growth on Climate Change in Arid or Semiarid Areas. - Advances in Earth Science 22(6):336-641.

[67] Zhao, H., Xiao, G., Wang, R., Deng, Z., Wang, H., Yang, Q. (2007b): Impact of Climate Change on Spring Wheat Growth in Semi-Arid Rain Feed Region. - Advances in Earth Science 22(3):322-327.

[68] Zhao, H., Sun, G., Wang, R. (2005): An analysis of the relation between occurrence of wheat aphid and climatically dynamics in Hedong over 20 years. - Advances in Earth Science 20:95-99. 